\title{
Dynamics of Tumor Hypoxia Measured with Bioreductive Hypoxic Cell Markers
}

Author(s) :Anna S. E. Ljungkvist, Johan Bussink, Johannes H. A M. Kaanders, and Albert J. van der Kogel

Source: Radiation Research, 167(2):127-145. 2007.

Published By: Radiation Research Society

DOI: http://dx.doi.org/10.1667/RR0719.1

URL: http://www.bioone.org/doi/full/10.1667/RR0719.1

BioOne (www.bioone.org) is a nonprofit, online aggregation of core research in the biological, ecological, and environmental sciences. BioOne provides a sustainable online platform for over 170 journals and books published by nonprofit societies, associations, museums, institutions, and presses.

Your use of this PDF, the BioOne Web site, and all posted and associated content indicates your acceptance of BioOne's Terms of Use, available at www.bioone.org/page/terms_of_use.

Usage of BioOne content is strictly limited to personal, educational, and non-commercial use. Commercial inquiries or rights and permissions requests should be directed to the individual publisher as copyright holder. 


\title{
Dynamics of Tumor Hypoxia Measured with Bioreductive Hypoxic Cell Markers
}

\author{
Anna S. E. Ljungkvist, ${ }^{1}$ Johan Bussink, Johannes H. A. M. Kaanders and Albert J. van der Kogel \\ Department of Radiation Oncology, Radboud University Nijmegen Medical Centre, Nijmegen, The Netherlands
}

Ljungkvist, A. S. E., Bussink, J., Kaanders, J. H. A. M. and van der Kogel, A. J. Dynamics of Tumor Hypoxia Measured with Bioreductive Hypoxic Cell Markers. Radiat. Res. 167, 127-145 (2007).

Hypoxic cells are common in tumors and contribute to malignant progression, distant metastasis and resistance to radiotherapy. It is well known that tumors are heterogeneous with respect to the levels and duration of hypoxia. Several strategies, including high-oxygen-content gas breathing, radiosensitizers and hypoxic cytotoxins, have been developed to overcome hypoxia-mediated radioresistance. However, with these strategies, an increased tumor control rate is often accompanied by more severe side effects. Consequently, development of assays for prediction of tumor response and early monitoring of treatment responses could reduce both overand undertreatment, thereby avoiding unnecessary side effects. The purpose of this review is to discuss different assays for measurement of hypoxia that can be used to detect changes in oxygen tension. The main focus is on exogenous bioreductive hypoxia markers (2-nitroimidazoles) such as pimonidazole, CCI-103F, EF5 and F-misonidazole. These are specifically reduced and bind to macromolecules in viable hypoxic cells. A number of these bioreductive drugs are approved for clinical use and can be detected with methods ranging from noninvasive PET imaging (low resolution) to microscopic imaging of tumor sections (high resolution). If the latter are stained for multiple markers, hypoxia can be analyzed in relation to different microenvironmental parameters such as vasculature, proliferation and endogenous hypoxia-related markers, for instance HIF1 $\alpha$ and CA-IX. In addition, temporal and spatial changes in hypoxia can be analyzed by consecutive injection of two different hypoxia markers. Therefore, bioreductive exogenous hypoxia markers are promising as tools for development of predictive assays or as tools for early treatment monitoring and validation of potential endogenous hypoxia markers. @ 2007 by Radiation Research Society

${ }^{1}$ Address for correspondence: Department of Radiation Oncology-874, Radboud University Nijmegen Medical Centre, 6500 HB Nijmegen, The Netherlands; e-mail: A.Ljungkvist@rther.umcn.nl.

\section{CLINICAL RELEVANCE OF HYPOXIA}

Clinically relevant levels of hypoxia are detected in about $50-60 \%$ of all solid tumors irrespective of size and histopathological features (1). Hypoxia is associated with tumor progression, increased aggressiveness, enhanced metastatic potential and a poor prognosis due to clonal selection or genomic or proteomic changes (2-6). In addition, hypoxia affects different anticancer treatments negatively.

More than half a century ago, it was demonstrated that the effect of radiation is affected by the oxygenation status of the tissue $(7,8)$. Over the past decades, evidence has accumulated showing that hypoxia is one of the major factors influencing radiotherapy negatively. Pretreatment oxygen tensions $\left(\mathrm{pO}_{2}\right.$ values) were predictive for local control and survival after surgery or radiotherapy in head and neck carcinomas and carcinomas of the uterine cervix (9-12). Different approaches have been developed to overcome treatment resistance caused by hypoxia, including the use of hypoxic cell sensitizers such as misonidazole and nimorazole (13), the use of vasoactive drugs such as nicotinamide (14), high-oxygen gas breathing under normo- or hyperbaric conditions (15-18), and hypoxic cytotoxins such as tirapazamine $(19,20)$. An analysis of 83 randomized clinical trials comparing radiotherapy alone and radiotherapy combined with treatments designed to modify or target tumor hypoxia showed that both local control and survival could be improved by reducing or specifically targeting tumor hypoxia (21).

Although oxygenation-modifying treatment protocols generally increase both local control rate and overall survival in several patient categories, not all of the patients treated benefit from these treatment approaches. Dynamic measurements of hypoxia during oxygenation-modifying treatments such as carbogen breathing could enable selection of responding and nonresponding patients. For the nonresponders, a reduction of unnecessary overtreatment would result in decreased side effects for these patients, allowing selection of another treatment modality that might be more appropriate, for example specifically targeting hypoxic cells, such as with tirapazamine. 
The purpose of this review is to give an overview of the relevance of tumor cell hypoxia and different techniques for detection and quantification of hypoxia. The main focus is on exogenous bioreductive hypoxia markers (2-nitroimidazoles), which label viable hypoxic cells. These hypoxia markers can be detected with various techniques, and by means of consecutive injection of two different hypoxia markers, temporal and spatial changes in hypoxia can be detected.

\section{PATHOPHYSIOLOGY OF HYPOXIA}

Various aspects of tumor biology, for example hypoxia and proliferation, are often studied in isolation. However, the tumor microenvironment comprises a dynamic system with complex structural and functional interactions. It is characterized by abnormal and heterogeneously organized tumor vasculature with reduced functionality (22-26), and considerable differences have been reported among tumors of the same localization, histology or differentiation grade. The intervascular distances are generally longer in tumors than in normal tissue (27-29), and tumors often have an imbalance between tumor cell proliferation and cell death. Consequently, tumor cells frequently outgrow the vasculature, which contributes to the development of tumor cell hypoxia.

In the 1950s and 1960s, corded tumor structures were described that consisted of blood vessels surrounded by viable tumor cells followed by necrosis at greater distances from the vessels. Thomlinson and Gray postulated that the expected oxygen diffusion distance in tissue would be approximately $150 \mu \mathrm{m}$, which was in accordance with the thickness of the cord of viable tumor cells $(22,30)$. It was suggested that the presence of necrosis could be explained by diffusion-limited starvation, with oxygen being a limiting factor. The presence of this kind of diffusion-limited, chronic hypoxia has been verified with bioreductive hypoxia markers such as CCI-103F, pimonidazole and EF5. The labeled tumor cells are generally found at greater distances from blood vessels, with increasing staining intensities along gradients of decreasing oxygen tensions. The most intensely stained cells are often located in the perinecrotic regions $(25,31-35)$.

Evidence of heterogeneous and intermittent blood flow has been obtained by window chamber studies of rat rhabdomyosarcomas (36). Complete occlusion of blood flow would result in rapid consumption of the remaining oxygen in the surrounding tissue. Therefore, it was suggested that perfusion-limited, acute hypoxia could occur as a consequence of transient changes in tumor blood flow (37). This was verified in vivo in experimental tumors by the use of two consecutively injected perfusion markers, Hoechst 33342 and $\mathrm{DiOC}_{7}$ (38). Complete vascular occlusions are rather uncommon; however, small changes in perfusion rate involving individual vessels or clusters of vessels frequently may occur (39-42). These can cause steep longitudinal gradients of oxygen and nutrients along vessels, resulting in transient periods of hypoxia $(43,44)$. The presence of tumor vessels with plasma flow but low or absent red blood cell flux indicates that diffusion-limited chronic hypoxia may also be present in the vicinity of blood vessels (42). Thus intermittent levels of hypoxia may originate from perfusion or diffusion limitations but more likely from a mixture of these (43), while the number of blood vessels in the tumor stroma does not necessarily reflect the tumor blood flow. Therefore, low perfusion rates and hypoxia may be present in tumor tissue despite high densities of (nonfunctional) vessels. Consequently, in many tumors the hypoxic cell population is heterogeneous with respect to the level and duration of hypoxia.

\section{DETECTION OF HYPOXIA}

The importance of hypoxia for radiation treatment and as a specific target for anticancer treatments (45) indicates the need for measurements of clinically relevant hypoxia. Therefore, assays are needed (1) for prediction of patient outcome, (2) as a tool to select treatments on an individual basis, and (3) for evaluation of early treatment response. To achieve this, further understanding of tumor cell hypoxia in relation to other clinically relevant parameters is necessary (46). Although several methods exist for detection of hypoxia, only the Eppendorf electrode $(9,47,48)$ and the bioreductive hypoxic cell markers pimonidazole and EF5 $(12,49)$ have shown prognostic significance in clinical studies or have been able to discriminate responders from nonresponders on a group basis.

The assays that are available for detection of tissue hypoxia can be divided into three major groups: (1) direct measurements of oxygen tension, (2) endogenous cell markers being expressed under hypoxic conditions, and (3) exogenous nitroimidazole-based assays $(5,50,51)$. The relevance of data obtained with the above-mentioned methods can be compared to the radiobiological hypoxic fraction obtained by the comet assay $(52,53)$ and paired survival curve assay $(54,55)$. Direct comparisons among studies using different assays are complicated due to the fact that the definitions of hypoxia, the spatial resolutions, and the timing of analyses differ. Most of the available assays provide static information about the tissue oxygenation status. However, some methods have been developed to allow measurements of changes in the oxygenation status over time.

\section{DEFINITIONS OF HYPOXIA}

Hypoxia can be described as the oxygen tension at which the metabolic demand in stroma, endothelial cells and tumor cells exceeds the supply. Oxygen tensions ranging from near atmospheric levels of $21 \% \mathrm{O}_{2}(159 \mathrm{mmHg})$ to $2-8 \%(15-60 \mathrm{mmHg})$ are found in normal tissues (56), making it difficult to define hypoxia as being at or below a specific $p \mathrm{O}_{2}$ value. Due to differences in experimental 
end points and in detection methods, several definitions of tumor hypoxia exist in the literature. Therefore, it is important to clearly define hypoxia in publications. Some of the most common definitions of tumor hypoxia are outlined below. The radiobiological hypoxic fraction is based on the difference in survival between tumors or cells irradiated under ambient compared to anoxic conditions. In in vitro studies, the hypoxic conditions for cell cultures are often defined as parts per million. Direct measurements of the oxygen tension with electrodes such as Eppendorf ${ }^{\text {Tim }}$ and OxyLite are commonly expressed in $\mathrm{mmHg}$, and tumor hypoxia is often defined as the fraction of measurements with a $p \mathrm{O}_{2} \leq 10,5$ or $2.5 \mathrm{mmHg}$. In contrast, hypoxia detected with exogenous bioreductive markers in immunohistochemically stained tumor sections is often expressed as the fraction of the tumor cells or surface that is labeled with the hypoxia marker. Therefore, caution has to be taken when different assays are compared. Throughout this review, hypoxia is generally defined as the proportion of cells with $p \mathrm{O}_{2} \leq 10 \mathrm{mmHg}$ corresponding to the oxygen tension below which a steep increase in reduction and binding of 2-nitroimidazoles is found.

\section{DIRECT MEASUREMENTS OF OXYGEN TENSION}

\section{Oxygen Electrodes}

Direct real-time measurements of oxygen tension in tissue can be performed with oxygen electrodes such as the Eppendorf ${ }^{\text {TWI }}$ polarographic needle electrode $(50,57,58)^{2}$ and the OxyLite fiber-optic probe (59-61). Despite differences in modes of action, measurements with the Eppendorf electrode and OxyLite ${ }^{\text {(iid }}$ probe result in comparable $p \mathrm{O}_{2}$ values in the range of $0-30 \mathrm{mmHg}(61,62)$.

The Eppendorf electrode consumes small amounts of oxygen and is moved throughout the tissue during measurements providing multiple samplings. The Eppendorf electrode provided the first clinical evidence that intratumoral oxygen tension was predictive of locoregional control (57) or survival in human cancers (63). Based on polarographic $p \mathrm{O}_{2}$ measurements, it was possible to separate responders from nonresponders in several clinical trials $(9$, 47, 48). Therefore, many investigators have considered Eppendorf measurements as a "gold standard" of hypoxia in human tumors $(46,50)$.

The OxyLite ${ }^{\text {(IX) }}$ probe does not consume oxygen during measurements and can be left at one position for a longer period $(61,64)$. OxyLite ${ }^{(10}$ can detect temporal fluctuations in $p \mathrm{O}_{2}$ of intrinsic origin (60) or changes induced by oxygen-modifying treatments such as carbogen breathing (59, $65)$ or hydralazine (66). In addition, the fiber-optic OxyLite $^{\text {(ix) }}$ probe is nonmagnetic and nonconducting, making it compatible with MR technology (61). Although it is a

\footnotetext{
${ }^{2}$ M. Nordsmark, Hypoxia Assessed by Oxygen Electrodes \& ${ }^{31} \mathrm{P}$ Magnetic Resonance Spectroscopy in Experimental Models and in Human Tumors, p. 121. Ph.D. thesis, University of Aarhus, Aarhus, 1997.
}

promising tool for monitoring dynamic changes in oxygen tension, OxyLite has been used only in experimental tumors. Therefore, Eppendorf and OxyLite ${ }^{\sqrt{10}}$ are not mutually exclusive but rather are complementary.

A general advantage of oxygen electrodes is the direct and rapid real-time measurements of absolute $p \mathrm{O}_{2}$ levels. However, due to the invasive nature of the measurements, these are feasible only in easily accessible tumors $(46,67)$. In addition, the spatial resolution is low, and measurements reflect the average oxygen tension over thousands of cells. Therefore, it is not possible to distinguish necrosis from severe hypoxia, which may bias measurements in tumors with substantial amounts of necrosis.

\section{Noninvasive Measurements of $\mathrm{pO}_{2}$}

MR-based assays provide noninvasive, low-resolution measurements of absolute $p \mathrm{O}_{2}$ values that are based on recorded spectra from paramagnetic agents. These paramagnetic agents can be either endogenous, such as oxyhemoglobin, or exogenous, such as charcoal emulsions or perfluorocarbons (68). When a contrast agent is not administered, MR techniques are noninvasive. The available techniques include the MR-based gradient recalled echo (GRE) imaging, magnetic resonance imaging (MRI) (68), electron paramagnetic resonance (EPR) oximetry $(69,70)$, magnetic resonance spectroscopy (MRS) (71-73), and spinlattice relaxation of fluorinated MR agents (74).

Blood oxygen-dependent level (BOLD) imaging is an MRI technique that is sensitive to the oxygenation status of hemoglobin. The BOLD contrast results from the endogenous change in paramagnetic deoxyhemoglobin, which results in a variation in MRI signals and offers a noninvasive tool to detect changes in tumor oxygenation without the need for an exogenous contrast agent $(75,76)$. The change in the oxygenation of rodent tumors upon carbogen breathing illustrates that BOLD functional MRI is a potential and promising application for monitoring the response of tissues to oxygenation-modifying treatments in the clinical setting.

The EPR technique uses paramagnetic contrast agents such as India ink or charcoal, which produce EPR spectra reflecting the absolute oxygen tension $(68,69)$. The intratumoral injection of the contrast agents is not trivial, and EPR is a technically demanding method that is yet to be validated in human tumors. However, it is a promising technique because one injection of a contrast agent is sufficient for repeated measurements over a relatively long period. Perhaps more important, it allows monitoring of changes in oxygenation induced by, for instance, carbogen breathing $(68,69,77-79)$. The in vivo applications of EPR in experimental tumors has made it clear that in vivo EPR has the potential to be applied (1) for selection of treatments on an individual basis based on pretreatment $p \mathrm{O}_{2}$ levels and (2) for evaluation of early responses during oxygen-modifying treatments. 


\section{INDIRECT MEASUREMENTS OF OXYGEN TENSION: ENDOGENOUS MARKERS OF HYPOXIA}

Hypoxia is a potent modulator of gene expression, regulating $1-2 \%$ of the genome $(56,80)$, including genes for growth factors that stimulate angiogenesis, cell proliferation and metastasis $(3,4,81-83)$. Genes and proteins involved in the "hypoxia response" have received interest as potential endogenous markers of hypoxia, and several of these proteins can be detected with immunohistochemistry. Among the candidates are hypoxia inducible factor 1 (HIF1), carbonic anhydrase IX (CA-IX), osteopontin and the facilitated glucose transporters 1 and 3 (GLUT1, GLUT3). A large number of the genes involved in the "hypoxia response" may not be directly dependent on low oxygen tensions; instead, expression could be induced by tumor and microenvironmental factors such as differentiation, availability of glucose and $\mathrm{pH}$. For instance, hypoxic cells often switch to anaerobic glycolysis, resulting in an increased need for glucose, followed by up-regulation of the GLUTs, eventually resulting in intracellular acidosis. Subsequently the cells can respond to the low $\mathrm{pH}$ with expression of CA-IX. However, hypoxia-independent up-regulation of those genes cannot be excluded completely. This complicates the interpretation of expression of endogenous hypoxia markers and explains some of the conflicting results obtained in clinical studies. Nevertheless, an advantage of endogenous hypoxia-related markers is that they can be analyzed both in archival material and in prospective clinical studies (51).

\section{Hypoxia Inducible Factor 1}

The transcription factor hypoxia inducible factor 1 (HIF1) plays an essential role in the adaptive response of cells to hypoxia and is one of the key regulators of oxygen homeostasis (84). Hydrolysis of its constitutively expressed $\alpha$ subunit becomes inhibited under hypoxia, followed by translocation to the nucleus. Heterodimerization of its $\alpha$ and $\beta$ subunits results in the active HIF1 protein that binds to specific hypoxia-responsive elements in target genes, ultimately activating transcription of these genes (85-87). Active HIF1 mediates trans-activation of more than 60 genes primarily involved in adaptation to hypoxia via glycolysis and angiogenic signaling $(87,88)$. Among the better-known HIF1-regulated gene products are vascular endothelial growth factor (VEGF), erythropoietin (EPO), facilitated glucose transporters 1 and 3 (GLUT1 and GLUT3) (86, 87, 89), and carbonic anhydrase IX (CA-IX) (90).

Since overexpression of HIF1A is common in solid tumors and their metastases $(91,92)$, the gene product has been evaluated as an endogenous hypoxia marker for several tumor types. Studies of head and neck, bronchus and brain tumors have shown an association between HIF1A and failure of locoregional control and/or impaired diseasefree survival (93-96), although in some tumors the opposite has been reported $(96,97)$. In addition to these inconsistent results, a poor correlation of HIF1A with bioreductive hypoxic markers such as pimonidazole and EF5 has been reported (98-100). Furthermore, expression of HIF1A has been reported in normally oxygenated tissues, which could reflect glucose depletion, activation of HIF1A protein synthesis or post-translational modification of the supporting actors $(80)$. Therefore, it is unlikely that HIF1A is specific enough to function as a surrogate marker of hypoxia.

\section{Carbonic Anhydrase IX}

Carbonic anhydrases participate in a variety of biological processes including $\mathrm{pH}$ regulation and respiration. The $C A 9$ gene encoding the tumor-associated carbonic anhydrase IX (CA-IX) is strongly up-regulated by hypoxia through HIF1 (90). Both the endogenous hypoxia-associated protein CAIX and the exogenous hypoxia marker pimonidazole can be detected with immunohistochemistry in tumor sections. Comparisons of CA-IX expression and pimonidazole binding by immunohistochemistry revealed similar patterns of staining but lacked an absolute spatial co-localization (12, 101-104). The lack of an absolute spatial match between pimonidazole and CA-IX suggests that it may become expressed at a different oxygen tension than the $p \mathrm{O}_{2}$ level at which pimonidazole becomes reduced and binds to tumor cells. In addition the slow induction and high stability of CA-IX may explain some of the observed spatial differences between CA-IX expression compared to binding of pimonidazole that was given shortly before tumor excision (105-108). However, the relationship between CA-IX expression and prognosis is unclear since studies with and without a significant association between these parameters have been reported $(12,101,104,109-112)$. CA-IX remains a promising endogenous marker of hypoxia since it demonstrates staining patterns similar to bioreductive hypoxia markers. Due to the kinetic profile of expression and turnover, it may be regarded as an indicator of longer periods of predominantly diffusion-limited hypoxia.

\section{Glucose Transporters}

Facilitated glucose transporters (GLUTs) mediate cellular glucose uptake and HIF1-mediated overexpression of glucose transporters has been demonstrated in vitro (113). Overexpression of the glucose transporters GLUT1 and GLUT3 has been reported in a variety of human cancers (114-119), and expression at distances further from the vasculature in perinecrotic areas suggests a relationship with diffusion-limited hypoxia $(120,121)$. In carcinomas of the uterine cervix, a significant correlation between GLUT1 and the exogenous hypoxia marker pimonidazole and between expression of GLUT1 and CA-IX was found. This further supports a relationship between GLUT1 and hypoxia (101). A weak correlation between GLUT1 and low $p \mathrm{O}_{2}$ values detected by oxygen microelectrodes has been reported in some but not all studies $(120,122)$. In addition, conflicting results have been reported regarding GLUT1 as 
an indicator of prognosis $(112,117,123)$. Therefore, it is still unclear whether the glucose transporters are specific enough to serve as endogenous hypoxia markers, and the clinical value of these as a prognostic factor remains unclear.

\section{Other Hypoxia-Related Proteins}

Examples of other hypoxia-induced proteins that are under investigation include IкB kinase $\beta$ (IKKB) (124), involucrin (125), ostepontin (126), the epidermal growth factor (EGFR) (127), and the activating transcription factor 4 (ATF4) (128). However, it has not yet been proven whether all these markers actually are up-regulated in vivo in hypoxic tumor areas. It was demonstrated by Le et al. that plasma osteopontin levels correlated with tumor hypoxia in head and neck carcinomas as measured by Eppendorf microelectrodes (126). In addition, the DAHANCA 5 randomized trial showed that high osteopontin levels are associated with poor outcome after radiotherapy. The poor outcome could be improved by the use of the hypoxic cell radiosensitizer nimorazole, and ostepontin could be used to identify patients in whom treatment outcome could be improved by hypoxia modification (129).

From the previous paragraphs it is clear that hypoxiaregulated genes may also be influenced by other stressors such as altered glucose and $\mathrm{pH}$ levels. Therefore, a proper understanding of how the tumor microenvironment regulates the expression of the endogenous hypoxia-related cell markers is needed before these can be implemented in clinical practice.

\section{INDIRECT MEASUREMENTS OF OXYGEN TENSION: EXOGENOUS HYPOXIC CELL MARKERS}

Exogenous hypoxic cell markers are drugs, chemicals or bacteria that, after administration, specifically accumulate or become reduced within tumor cells under hypoxic conditions.

Bacteria such as intravenously injected clostridia spores have the ability to infiltrate and selectively colonize hypoxic/necrotic regions of experimental tumors. The bacteria can be genetically engineered to secrete therapeutic proteins such as tumor necrosis factor $\alpha$ (130) or to express a reporter gene encoding, for instance, green fluorescent protein (GFP) (131). Expression of the reporter gene provides information about the regions in which the bacteria accumulate. Although reporter genes have been detected so far only by imaging of small animals, it is a technique that can become useful for monitoring delivery of therapeutic proteins specifically targeting hypoxia cells.

One of the most sensitive methods for detecting hypoxia is based on the observation that binding of 2-nitroimidazoles to cellular macromolecules occurs as a result of hypoxia-dependent irreversible bioreduction by cellular nitroreductases at $p \mathrm{O}_{2}$ levels below approximately $10 \mathrm{mmHg}$
(132-134). Reduction and binding are integrated over the time of drug exposure under hypoxic conditions and are inhibited as a function of increasing oxygen concentration. Several 2-nitroimidazoles can be used as hypoxia markers and provide an inverse and indirect measurement of tumor oxygenation. Some of the features of the most commonly used 2-nitroimidazoles such as CCI-103F $(135,136)$, misonidazole (137-139), pimonidazole $(132,140)$ and EF5 $(133,141)$ are listed in Table 1 . The latter three are approved for clinical use, and several methods are available for detection of these markers. For instance, radioactively labeled 2-nitroimidazoles can be detected by noninvasive methods such as PET (142-144), MRS $(71,136)$ and SPECT (144) or by autoradiography (138). Antibodies raised against reduced and bound bioreductive markers can be used for detection of hypoxic cells by means of three different immunoassays; the enzyme-linked immunosorbent assay (ELISA), flow cytometry (FCM) or immunohistochemistry (IHC) of frozen or paraffin-embedded sections (132, 133, 145-152). Table 2 shows an overview of the assays that are suitable for detection of the most common 2-nitroimidazoles.

The ring structure and the nitro group are characteristic features of all 2-nitroimidazoles, resulting in a similar oxygen dependence of these drugs. However, the pharmacokinetics and accumulation rates of these drugs differ because of unique properties of the side chains (Table 1). For instance, at simultaneous administration or at short times between injection, pimonidazole binds more extensively (factor of 1.1-1.2) and more rapidly than CCI-103F (153155). Only 30 to $60 \mathrm{~min}$ is needed for distribution and binding of pimonidazole for visualization by immunohistochemistry compared to $2.5 \mathrm{~h}$ for CCI-103F (Table 2). The reduction and binding of 2-nitroimidazoles are dependent on oxygen, but the total amount of bound marker is also affected by the accumulation rates in individual hypoxic cells. In contrast to CCI-103F and EF5, the accumulation rate of pimonidazole is dependent on $\mathrm{pH}$. This can explain the excess of pimonidazole binding that occurs mainly at the vessel side of the diffusion-limited hypoxia, corresponding to the area with an increasing gradient between the intracellular and extracellular $\mathrm{pH}$. There is reason to assume that transient hypoxia will be preferentially detected by pimonidazole since regions of fluctuating hypoxia are likely to occur in the vicinity of the blood vessels.

The reduction and subsequent binding of the bioreductive markers require not only hypoxia but also intact nitroreductase enzymes (156). Therefore, these markers detect only viable hypoxic cells and not necrotic cells. Differences in nitroreductase activities among different cell types can affect the intracellular concentration of reduced intermediates in hypoxic cells. This may contribute to discrepancies in the quantitative analysis of hypoxia, especially in tumors of different origins.

The reduced marker intermediates bind to cellular macromolecules, with proteins being the major binding site 
TABLE 1

Some Features of the most Commonly Used 2-Nitroimidazoles

\begin{tabular}{|c|c|c|c|c|c|c|c|c|c|c|}
\hline \multirow[b]{2}{*}{ Marker name } & \multirow[b]{2}{*}{ Chemical name } & \multirow{2}{*}{$\begin{array}{c}\text { Solvent } \\
P=\text { octanol/ } \\
\text { water }\end{array}$} & \multirow{2}{*}{$\begin{array}{c}\text { Dose } \\
\text { (species) }\end{array}$} & \multicolumn{3}{|c|}{ Plasma half-life } & \multirow{2}{*}{$\begin{array}{l}\text { Clinically } \\
\text { approved } \\
\text { (regions of use) }\end{array}$} & \multirow{2}{*}{$\begin{array}{c}\mathrm{T} / \mathrm{P}^{a} \mathrm{~T} / \mathrm{B}^{b} \\
\mathrm{~T} / \mathrm{M}^{c}\end{array}$} & \multirow[b]{2}{*}{$\mathrm{K}_{\mathrm{m}}(\mathrm{ppm})^{d}$} & \multirow[b]{2}{*}{ Reference(s) } \\
\hline & & & & Rodent & Dog & Man & & & & \\
\hline $\begin{array}{l}\text { Misonidazole Ro } \\
\text { 07-0582 }\end{array}$ & $\begin{array}{l}\text { 1-(2-Hydroxy-3- } \\
\text { methoxypropyl)- } \\
\text { 2-nitroimidazole }\end{array}$ & $P=0.4$ & $\begin{array}{l}25-100 \mu M^{e} \\
\text { (mice) }\end{array}$ & $25-45 \mathrm{~min}$ & $\begin{array}{l}3.7 \text { h } \\
\text { (i.v.) } 5 \\
\text { h (oral } \\
\text { admin- } \\
\text { istra- } \\
\text { tion) }\end{array}$ & $9.3 \mathrm{~h}$ & Yes & $\mathrm{T} / \mathrm{B} \approx 8$ & $\approx 1000-3000$ & $(138,205-209)$ \\
\hline $\begin{array}{l}\text { NITP (A2-nitrom- } \\
\text { idazole) }\end{array}$ & $\begin{array}{l}\text { 7-(4'-(2-nitroimida- } \\
\text { zol-1-yl)-butyl)- } \\
\text { theophylline }\end{array}$ & $\begin{array}{l}\text { Peanut oil and } \\
10 \% \text { DMSO }\end{array}$ & $\begin{array}{l}156 \mathrm{mg} \mathrm{kg}^{-1} \\
\text { (mice) }\end{array}$ & $\begin{array}{l}\text { Stable during } \\
\text { the first } 50 \\
\text { min, then } 33 \\
\text { min }\end{array}$ & & & No & & $1400 \mathrm{ppm}$ & $\begin{array}{l}(151,173, \\
210,211)\end{array}$ \\
\hline CCI-103F & $\begin{array}{l}\text { (1-(2-hydroxy-3- } \\
\text { hexafluoroisopro- } \\
\text { poxy-propyl)-2- } \\
\text { nitroimidazole) }\end{array}$ & $\begin{array}{l}\text { Peanut oil and } \\
10 \% \mathrm{DMSO} \\
\text { or } 0.9 \% \mathrm{NaCl} \\
P=20\end{array}$ & $\begin{array}{l}60-80 \mathrm{mg} \\
\mathrm{kg}^{-1} \text { (mice) } \\
200 \mu M \\
\text { (rat) } 40 \mathrm{mg} \\
\mathrm{kg}^{-1} \text { (dog) }\end{array}$ & $40-90 \mathrm{~min}$ & $7-8 \mathrm{~h}$ & & No & $\mathrm{T} / \mathrm{P} \approx 0.8$ & & $\begin{array}{r}(31,136 \\
137,147 \\
148,212)\end{array}$ \\
\hline $\begin{array}{c}\text { Pimonidazole (Ro } \\
\text { 03-8799) Hy- } \\
\text { poxyprobe }^{\mathrm{TM}}-1\end{array}$ & $\begin{array}{l}\text { (1-(2-nitro-1-imid- } \\
\text { azolyl)-3- } N \text {-pi- } \\
\text { peridino-2-propa- } \\
\text { nol) }\end{array}$ & $\begin{array}{l}0.9 \% \mathrm{NaCl} P= \\
\quad 8.0\end{array}$ & $\begin{array}{l}60-80 \mathrm{mg} \\
\mathrm{kg}^{-1}(\mathrm{mice}) \\
0.5 \mathrm{gm}^{-2} \\
\max 1 \mathrm{~g} \\
\text { (humans) } \\
0.285 \mathrm{gm}^{-2} \\
\text { (dogs) }\end{array}$ & $\begin{array}{c}\sim 30 \mathrm{~min} \text { in } \\
\mathrm{C} 3 \mathrm{H} \text { mice }\end{array}$ & $1.5 \mathrm{~h}$ & $5-6 \mathrm{~h}$ & $\begin{array}{l}\text { Yes (Canada, } \\
\text { Europe, } \\
\text { USA) }\end{array}$ & $\mathrm{T} / \mathrm{P} \approx 3$ & $\begin{aligned} \approx & 1500 \mathrm{ppm} \\
& (0,15 \%)\end{aligned}$ & $\begin{array}{l}(33,133 \\
148,177 \\
208,213 \\
214)\end{array}$ \\
\hline EF5 & $\begin{array}{l}\text { [2-(2-nitro-1H-imi- } \\
\text { dazol-1-yl)- } N \text { - } \\
\text { (2,2,3,3,3-penta- } \\
\text { fluoropropyl) } \\
\text { acetamide] }\end{array}$ & $\begin{array}{l}0.9 \% \mathrm{NaCl} \text { (rat) } \\
5 \% \text { dextrose } \\
\text { in water with } \\
2.5 \% \text { alcohol } \\
\text { (man) } P=4, \\
0-5.7\end{array}$ & $\begin{array}{l}100 \mu M \text { (rat) } \\
9-21 \mathrm{mg} \\
\mathrm{kg}^{-1} \text { (hu- } \\
\text { man) }\end{array}$ & $150 \mathrm{~min}$ (rat) & & $12-14 \mathrm{~h}$ & Yes (USA) & & & $\begin{array}{l}(162,208, \\
215)\end{array}$ \\
\hline $\begin{array}{l}\text { F-MISO ( }{ }^{18} \text { F-fluo- } \\
\text { ro-misonidazo- } \\
\text { le) }\end{array}$ & $\begin{array}{l}\text { [18F]1-(2-nitro-1- } \\
\text { imidazolyl)-3- } \\
\text { fluoro-2-propanol }\end{array}$ & $\begin{aligned} P & =2.6 \text { (also } P \\
& =0.43 \text { have } \\
& \text { been report- } \\
& \text { ed) }\end{aligned}$ & & $\sim 40 \mathrm{~min}$ & & $5-10 \mathrm{~h}$ & $\begin{array}{l}\text { Yes (Australia, } \\
\text { Europe, } \\
\text { USA) }\end{array}$ & $\mathrm{T} / \mathrm{B} \approx 2-3$ & & $(165)$ \\
\hline
\end{tabular}

${ }^{a}$ Tumor to plasma ratio.

${ }^{b}$ Tumor to blood ratio.

$c$ Tumor to muscle ratio.

${ }^{d}$ May differ among tumor types for a certain marker.

${ }^{e}$ In both spheroids and plasma.

TABLE 2

Overview of Available Assays for the most Common 2-Nitroimidazoles

\begin{tabular}{|c|c|c|c|c|}
\hline Marker name & $\begin{array}{l}\text { Time to tumor excision } \\
\text { (minimum) }\end{array}$ & $\begin{array}{c}\text { Stability of bound } \\
\text { marker/turnover } \\
\text { in tissue (tumor dependent) }\end{array}$ & Detection method & Reference(s) \\
\hline Misonidazole & $\begin{array}{l}3 \mathrm{~h} \text { before detection, injection } \\
\text { was repeated after } 1 \mathrm{~h} \text { and } 2 \\
\mathrm{~h} \text { to maintain stable serum } \\
\text { levels over the } 3 \mathrm{~h} \text { (mice) }\end{array}$ & $50-55 \mathrm{~h}$ in mice & $\mathrm{ARG}^{a}$ & $(138)$ \\
\hline NITP (A2-nitroimidazole) & $1-2 \mathrm{~h}$ in mice & $\begin{array}{l}\text { At least } 28 \mathrm{~h} \text { in anaplastic sar- } \\
\text { coma } \mathrm{SaF} \text { in } \mathrm{CBA} / \mathrm{Ht} \text { Gy TO } \\
\text { mice }\end{array}$ & $\mathrm{FCM}^{b} \mathrm{IHC}^{c}$ & $(146,210,211)$ \\
\hline CCI-103F & $2 \mathrm{~h}$ in mice, $24 \mathrm{~h}$ in dogs & $\begin{array}{l}\text { Turnover: Mean }=19 \mathrm{~h} \text { in } \\
\text { dogs, Mean }=8 \mathrm{~h} \text { in mice }\end{array}$ & ELISA, ${ }^{d}$ FCM, IHC & $(147)$ \\
\hline $\begin{array}{l}\text { Pimonidazole (Ro 03- } \\
\text { 8799) }\end{array}$ & $\begin{array}{l}30-60 \text { min in mice, } \geq 2 \mathrm{~h} \text { in } \\
\text { patients }\end{array}$ & Up to 5 days & ELISA, FCM, IHC & $(154)$ \\
\hline $\begin{array}{l}\text { EF5 } \\
\text { F-MISO }\left({ }^{18} \text { F-fluoro-mi- }\right. \\
\quad \text { sonidazole })\end{array}$ & $3 \mathrm{~h}$ in mice, $24 \mathrm{~h}$ in patients & At least $24 \mathrm{~h}$ & $\begin{array}{l}\text { IHC, PET, FCM } \\
\text { PET }\end{array}$ & $(215,216)$ \\
\hline
\end{tabular}

${ }^{a}$ Autoradiography.

${ }^{b}$ Flow cytometry.

${ }^{c}$ Immunohistochemistry.

${ }^{d}$ Enzyme-linked immunosorbent assay. 
(135), and after binding both the side chain and the ring structure are retained (157-160). Upon binding, the 2-nitroimidazoles are fairly stable, but ultimately these will become metabolized. Differences in the stability of reduced and bound markers have been reported, indicating that intracellular pimonidazole and ${ }^{18} \mathrm{~F}$-misonidazole labeling are more stable than CCI-103F labeling $(146,147)$. As an explanation, it was suggested that the more hydrophobic side chain of CCI-103F could be more prone to hydrolysis than the hydrophilic side chain of pimonidazole (147). Potentially, metabolism of bound adducts could be caused by generalized protein turnover or cell division. However, other mechanisms are involved as well, since differences in the turnover rates of reduced CCI-103F or pimonidazole adducts have been observed among spontaneous canine tumors $(146,147)$. In addition, turnover rates of hypoxic tumor cells ranging from 16 to $54 \mathrm{~h}$ were observed among different solid tumor lines (154). Therefore, the stability of the bound marker in viable tumor tissue and the different hypoxic cell turnover rates should be taken into account when assessing hypoxia in tumors that are excised or biopsied later than 16-24 $\mathrm{h}$ after injection of the hypoxia markers.

As mentioned earlier, binding of 2-nitroimidazoles in hypoxic cells is integrated over the exposure time, and the labeled cells are often separated from the vasculature by several layers of nonstained relatively normally oxygenated cells. Therefore, it is assumed that 2-nitroimidazoles predominantly label diffusion-limited hypoxic cells $(12,25$, $31,33,151,161)$. However, repeated short episodes of hypoxia may also be detected, which could explain the presence of pimonidazole binding near functional, perfused blood vessels within 30-60 min after injection of the hypoxia marker (152). Similarly, tumor cells labeled with both a bioreductive hypoxia marker and a subsequently injected S-phase marker (indicating replicative DNA synthesis) may be transiently hypoxic $(149,150,162)$, although such overlap could also be present in intermediate hypoxic areas.

\section{Radiolabeling of 2-Nitroimidazoles}

Most radiolabeled probes for the detection of hypoxia have the radioactive element attached to bioreductive hypoxia markers, which generally are 2-nitroimidazoles. The ideal tracer should be highly specific and readily incorporated in hypoxic cells with a rapid washout. Subsequently, the activity detected by PET or SPECT imaging should reflect the uptake with a good signal-to-noise ratio. The data on hypoxia can be assessed quantitatively in relation to additional biological and pathological characteristics of tissue such as metabolism, proliferation and blood flow (163). The isotopes ${ }^{123}$ (IAZA) and ${ }^{99 \mathrm{~m}} \mathrm{Tc}$ (HL91) are available for SPECT, and ${ }^{18} \mathrm{~F}$ (F-miso, EF5, FAZA and FETNIM), ${ }^{60} \mathrm{Cu}\left(\mathrm{Cu}\right.$-ATSM) and ${ }^{124}$ (IAZGP) are available for PET (144). Although the clinical experience is limited for some of the isotopes, all but FAZA and IAZGP have been used in the clinic. So far, the most widely studied imaging agent for hypoxia is ${ }^{18} \mathrm{~F}$-MISO. Since the half-life of ${ }^{18} \mathrm{~F}$ is as short as $110 \mathrm{~min}$, the utility of ${ }^{18} \mathrm{~F}$-MISO is limited mainly by its slow clearance kinetics, which delay specific imaging for up to 2-3 h after injection (164). Grönroos et al. reported that ${ }^{18} \mathrm{FAZA}$ and ${ }^{18} \mathrm{FETNIM}$ seem to be as feasible as ${ }^{18} \mathrm{~F}-\mathrm{MISO}$. An advantage of ${ }^{18} \mathrm{FAZA}$ and ${ }^{18} \mathrm{FETNIM}$ is the rapid clearance rates allowing shorter intervals between injection and measurements compared to ${ }^{18} \mathrm{~F}-\mathrm{MISO}$ (164, 165).

Several small clinical studies including advanced head and neck cancer, lung cancer, cervical carcinomas and prostate cancer indicate that detection of hypoxia with PET is feasible. An advantage of ${ }^{18} \mathrm{~F}-\mathrm{MISO}$ PET is that it can be used repeatedly for tumor diagnosis and treatment followup. In addition, it has been demonstrated for various tumor sites that PET-based imaging of hypoxia has potential for monitoring the effect of therapy and predicting tumor response (166-169). Therefore, FMISO PET has a great potential to become an important and useful tool for prognostic and predictive assays, especially in patients where surgery is not indicated, and repeated scans may provide a tool to revise treatment strategies.

Analysis of PET in relation to CT can detect some degree of spatial heterogeneity of hypoxia at the macroscopic level $(144,170)$. Nevertheless, it should be kept in mind that each voxel $(5 \mathrm{~mm})$ in a clinical PET image integrates the oxygenation status of several tumor cords. For instance, Wijffels et al. showed that in advanced HNSCC the vascular density was 41 to 305 vessels $/ \mathrm{mm}^{2}$ (33). Therefore, it can be assumed that $1 \mathrm{~mm}^{3}$ contains approximately 260 to 5360 vessels. With a PET voxel size of $5 \mathrm{~mm}^{3}$, the average number of tumor vessels in each voxel is immense. A disadvantage of PET is that it does not allow discrimination between microregional necrosis and viable nonhypoxic (MISO negative) tumor cells. Another disadvantage of PET imaging of 2-nitroimidazoles is the need to use short-lived isotopes such as ${ }^{123} \mathrm{I}$ and ${ }^{18} \mathrm{~F}$, requiring a cyclotron either on site or nearby (171).

In experimental studies, immunohistochemistry of CCI$103 \mathrm{~F}$ yielded comparable patterns of binding compared to autoradiography of misonidazole in both spheroids and tumor sections (135). Also, the patterns of pimonidazole detected with immunohistochemistry were comparable to autoradiography of misonidazole (140). These studies indicate that those markers have similar oxygen dependences.

\section{Immunodetection of 2-Nitroimidazoles}

Reduced and bound 2-nitroimidazoles are stable in tumor cells during normal histological processing, and detection with antibodies is a relatively rapid method. CCI-103F was the first (135) and NITP (172) was the second hypoxia marker that could be detected by means of antibodies. A disadvantage of these substances was the poor water solubility. In mice, a vehicle of DMSO and peanut oil was 
necessary for intraperitoneal administration, and these markers were never approved for clinical use (172). This led to the development of antibodies against more suitable hypoxia markers such as EF5 (173) and pimonidazole (132). Unfortunately, attempts to raise antibodies against reduction products of misonidazole, the most widely used imaging agent, resulted in antibodies with relatively weak specificity that were unsuitable for general use (171).

\section{Enzyme-Linked Immunosorbent Assay}

The enzyme-linked immunosorbent assay (ELISA) is an easy and rapid method for quantitative analysis of the concentration of bound hypoxia marker in a large number of tumor cells. Since cell lysates are used for the measurements, the assay does not give information about the number of labeled cells or their spatial distribution. In addition, with ELISA no discrimination can be made between normal and tumor cells. Moreover, this assay cannot distinguish between a large number of cells with low to intermediate binding and a low number of cells with high-intensity binding of the hypoxia markers, since each of these situations may result in the same antigen concentration. All quantitative measurements of the amounts of reduced and bound bioreductive markers may be affected by intertumoral differences in reductase levels. However, due to the use of total cell lysates, ELISA is more sensitive to intertumoral differences in reductase activities compared to assays that detect hypoxia marker labeling as function of labeled tumor surface fraction or of the fraction labeled intact tumor cells. An advantage of ELISA is that it is suitable for rapid screening of the presence or absence of tumor cell hypoxia in large series $(146,147,174)$.

\section{Flow Cytometry}

Flow cytometry allows rapid analysis of a large number of tumor cells in single cell suspension. Using triple staining, hypoxia can be compared to other tumor cell markers on an individual cell basis $(148,150)$. In addition, cell sorting of hypoxic cells, based on the fluorescence intensity of the perfusion marker Hoechst 33342, provides information about the distribution of hypoxic cells as a function of the distance from the perfused (functional) blood vessels (148, 175). Simultaneous analysis of NITP, BrdUrd and total DNA content analyzed with flow cytometry provided the first evidence of a small hypoxic cell population in active cell cycle (150). Analysis of bioreductive hypoxic cell markers in relation to markers of cell proliferation in tumor sections confirmed this observation (149), but proliferating hypoxic cells may not be present in all tumors (148).

\section{Tumor Sections}

Immunostaining of tumor sections for 2-nitroimidazoles allows microscopic image analysis of the spatial distribution of individual hypoxic cells relative to microenvironmental parameters such as vasculature, proliferation and en- dogenous hypoxia-related markers $(12,25,33,101,102$, $149,176)$. This provides in vivo-ex vivo information of the physiology of hypoxic cells in relation to other important cellular processes (Fig. 1). Immunohistochemical analysis of exogenous hypoxia markers has been applied in both experimental and clinical studies. Also, direct comparisons can be made between primary tumors and the corresponding xenografts such as illustrated by a comparison of the endogenous proliferation marker (Ki67) between patient biopsies and the corresponding xenografts (177). In experimental tumor models, intratumoral changes in hypoxia can be analyzed by means of consecutive injections of two different hypoxia markers (Fig. 2). It is also possible to combine microscopic analysis of 2-nitroimidazoles with other imaging modalities such as PET.

In tumor sections, hypoxia can be quantified by estimating the fractions of stained cells by visual semi-quantitative scoring or digital image analysis $(12,25,100,151,178)$. Hypoxia can also be quantified as a function of the fluorescence intensity of bound markers calibrated against in vitro binding of the bioredcutive markers in hypoxic cells at a known $p \mathrm{O}_{2}(67)$. In tumor sections from patients with head and neck carcinomas of the same stage and anatomical origin, three different spatial patterns of hypoxic tumor cells were observed: (1) patchy hypoxia, (2) band-like hypoxia at large distances from the vasculature, and (3) tumors with hypoxia near the tumor vasculature (33). These have also been observed in human tumors of different origin and in canine tumors as well as in xenografts of human head and neck carcinomas grown in nude mice $(25,31,149)$. The clinical relevance of the hypoxia patterns is not yet known, but they may be related to hypoxia tolerance, hypoxic cell turnover rate and cell loss.

\section{APPLICATIONS OF IMMUNOHISTOCHEMICAL ASSAYS}

\section{Predictive Value of Pimonidazole}

As mentioned earlier, tumor cell hypoxia contributes to resistance to radiation. In addition, the efficacy of oxygenmodifying treatments aimed at improving tumor oxygenation may vary among individual patients. Therefore, development of reproducible and rapid predictive assays may improve the ability to select patients that would benefit from specific oxygen-modifying treatments. In a recent clinical study of head and neck tumors, high pimonidazole binding correlated with poor treatment outcome (12). This has also been observed with EF5 in soft tissue sarcomas (49). In the head and neck study, the benefit of hypoxiabased intervention with ARCON [accelerated radiotherapy combined with carbogen $\left(95 \% \mathrm{O}_{2}\right.$ and $\left.5 \% \mathrm{CO}_{2}\right)$ and nicotinamide] was confirmed since the predictive power of pimonidazole binding disappeared in the ARCON-treated group (12). Although these results are promising, the clinical experience with exogenous hypoxia markers is limited 

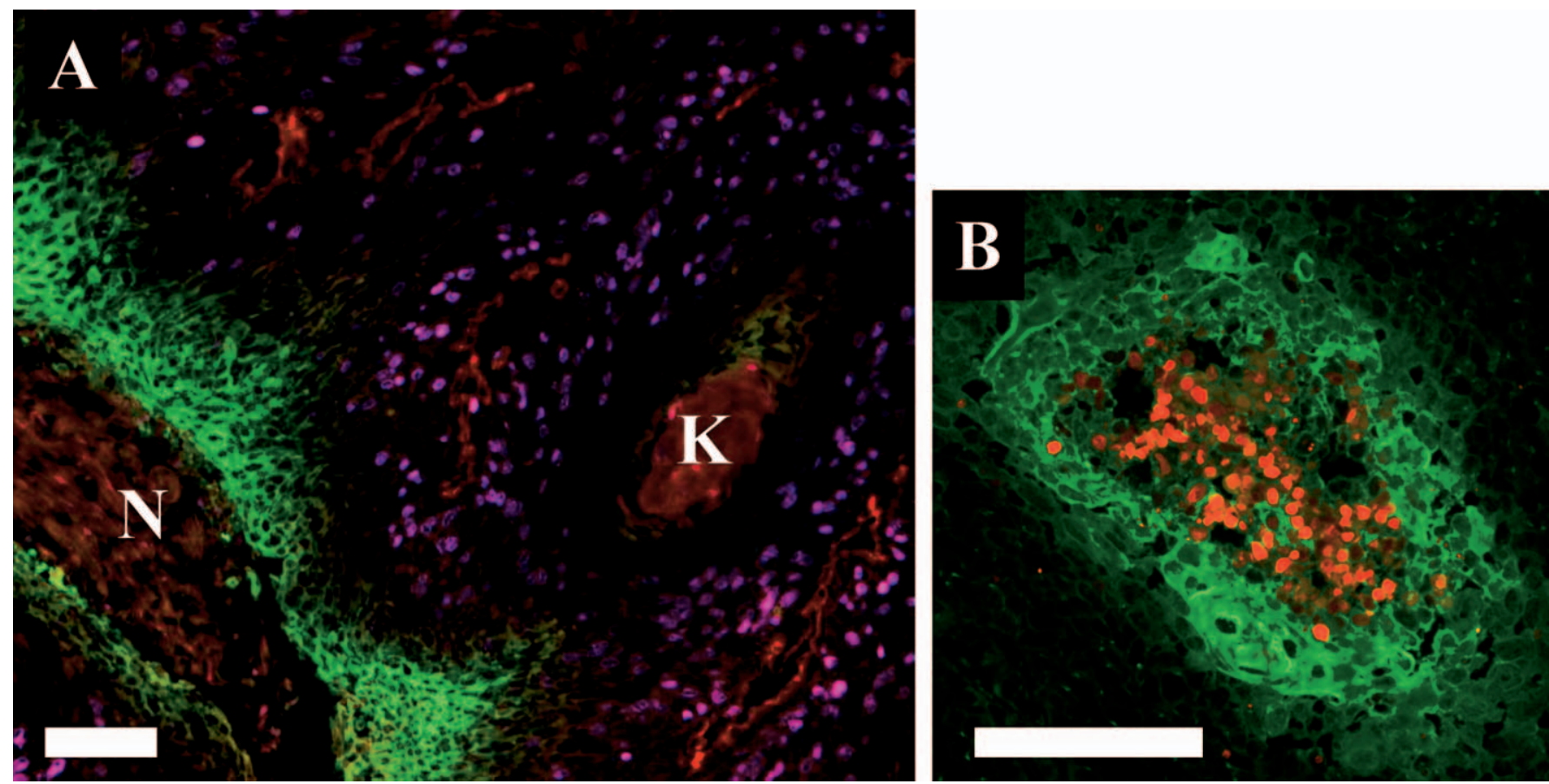

FIG. 1. Photomicrographs of patient biopsies of human head and neck squamous cell carcinomas. Panel A: The SCCNij53 tumor at $100 \times$ magnification showing hypoxia (green, pimonidazole) in relation to vasculature (red, pal-E) and proliferation (purple, IdUrd). Panel B: A detail of the SCCNij70 tumor at $200 \times$ magnification showing a hypoxic area (green) enclosing apoptotic cells stained with the TUNEL assay (red). Necrosis (N) and keratin (K); scale bar is $100 \mu \mathrm{m}$.

to studies with small numbers of patients. The possibility to use pimonidazole as a predictive marker will be evaluated in an ongoing randomized phase III ARCON trial (179), in which the most promising endogenous markers of hypoxia and proliferation will also be validated against pimonidazole binding.

Novel assays such as assessment of hypoxia with the bioreductive markers pimonidazole and EF-5 have been compared to the Eppendorfin electrode since the latter has been regarded as the gold standard for clinical studies. One study showed a correlation between the hypoxic fraction determined by pimonidazole binding and $p \mathrm{O}_{2}(180)$, while others did not report significant correlations (181-183). The poor spatial resolution in the electrode data compared to the detailed microregional information obtained by the hypoxia markers can explain some of the discrepancies between these assays $(182,183)$. In contrast, the hypoxic fraction of pimonidazole correlated better with the radiobiological hypoxic fraction in individual cells assessed by the comet assay than with Eppendorf measurements. This demonstrates the limitations of the Eppendorf ${ }^{\mathrm{mix}}$ method at the microregional and cellular levels (50). The hypoxic fractions determined using pimonidazole or EF5 measured in tumor biopsies predicted outcome for patients treated with radiotherapy $(12,49)$ and may therefore become a new gold standard for assays detecting hypoxia at the cellular level.

\section{Dynamics of Hypoxia: Consecutive Injection of Hypoxia} Markers

In tumor sections stained for hypoxia markers, treatmentinduced changes in hypoxia can be visualized in relation to the vascular architecture and other cellular markers. In the xenografted human squamous cell carcinoma SCCNij3, carbogen breathing resulted in a decrease of hypoxia, detected with NITP, and of proliferation, detected with BrdUrd, compared to the air-breathing control animals. Thus a simultaneous improvement in oxygenation (reduced hypoxia) and decrease in tumor cell proliferation were observed and quantified (184). This technique has also been applied in human tumors grown as xenografts to study for instance the effects of the antiangiogenic compound SU-5416 (185) or radiation (151) on hypoxia in relation to vasculature and blood perfusion.

A pioneering study using two consecutively injected perfusion markers, Hoechst $33342(175,186)$ and DiOC7(3) (187, 188), provided direct evidence of transient changes in blood perfusion in vivo (38), suggesting the presence of temporal fluctuations in tumor oxygenation. It inspired development of double hypoxia marker assays with consecutive injections of two different 2-nitroimidazoles for analysis of changes in hypoxia in individual experimental tumors $(153,154,164,189-192)$. Since each tumor serves as its own control, these assays eliminate the effect of in- 


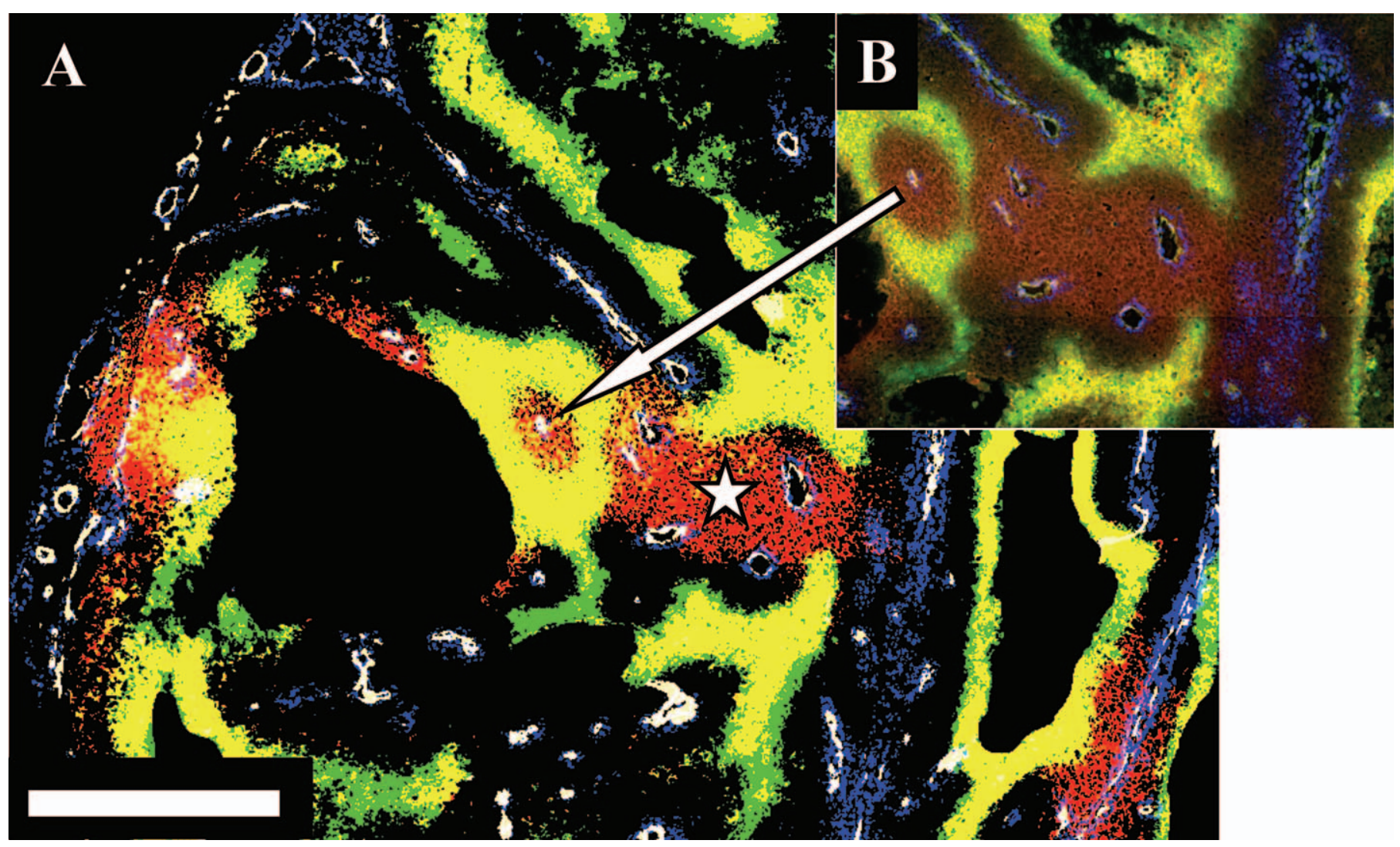

FIG. 2. Panel A: Composite binary image of a human mucoepidermoid carcinoma MEC 82 that was grown as a xenograft in nude mice, with vasculature (white), perfusion marker Hoechst 33342 (blue), first hypoxia marker (pimonidazole, green), and second hypoxia marker (CCI-103F, red). Spatial co-localization of both markers (red + green) appears as yellow. At an injection interval of $2 \mathrm{~h}$, most of the hypoxic cells were labeled by both the first and second hypoxia marker. Transient hypoxia is illustrated as an area that was not hypoxic at the time of the injection of the first marker but had become hypoxic at the time of the second hypoxia marker injection (red only, star in panel A). Panel B: A detail of the area with transient hypoxia. The brightness of the colors reflects the differences in staining intensities in the original grayscale scans. Scale bar $=500 \mu \mathrm{m}$.

tertumor heterogeneities in hypoxic fractions within the same tumor line and histology.

The first double hypoxia marker study used $\beta$-D-iodinated azomycin galactoside (IAZG) labeled with iodine-125 and $\beta$-D-iodinated azomycin xylopyramoside (IAZXP) labeled with iodine-131. The hypoxia markers were detected with SPECT. Upon co-injection in rodent tumors, the intratumoral variation of the two markers was only $4 \%$. In contrast, at an injection interval of 2.5 to $3 \mathrm{~h}$, a mismatch that was larger than $8 \%$ was found in 8 of 18 tumors. This was interpreted as evidence for significant amounts of transient hypoxia (190). With this assay, significant changes in labeling between the first and second marker were found upon treatment with carbogen and nicotinamide. An advantage of that assay was that two almost identical hypoxia markers were used, but a disadvantage was the poor spatial resolution. In a study of human tumors grown as xenografts, sequential administration of multiple doses of pimonidazole resulted in significantly larger hypoxic fractions compared to a single administration of CCI-103F. The hypoxia markers were detected by means of flow cytometry, and the difference between pimonidazole and CCI$103 \mathrm{~F}$ was interpreted as the amount of hypoxic cells ex- posed to intermittent periods of hypoxia. The proportion of tumors with transient hypoxia was $20 \%$ in SiHa tumors compared to $8 \%$ in WiDr tumors, indicating that large heterogeneities exist between solid tumors of different histology and origin (189). The presence of transient hypoxia can also be detected by means of immunohistochemistry upon sequential injection of two hypoxia markers. Presumably, the tumor cells that are labeled with only the first or only the second hypoxia marker in the human head and neck tumor line grown as xenograft (Fig. 2) experienced transient changes in hypoxia during the 2-h interval between the injections of the hypoxia markers.

Upon consecutive injection of the two hypoxia markers, microscopic image analysis of tumor sections can be used for analysis of both spatial and temporal changes in hypoxia in relation to the vascular architecture and other cellular markers $(153,154,191)$. Examples of applications using this technique include changes in hypoxia during carbogen breathing $(153,191)$, after hydralazine treatment (153), and after irradiation (192). In addition, the dynamics of hypoxic cells in untreated tumors have been analyzed with this technique (154). By varying the sequence of injection of pimonidazole and CCI-103F, the pharmacokinetic differences 

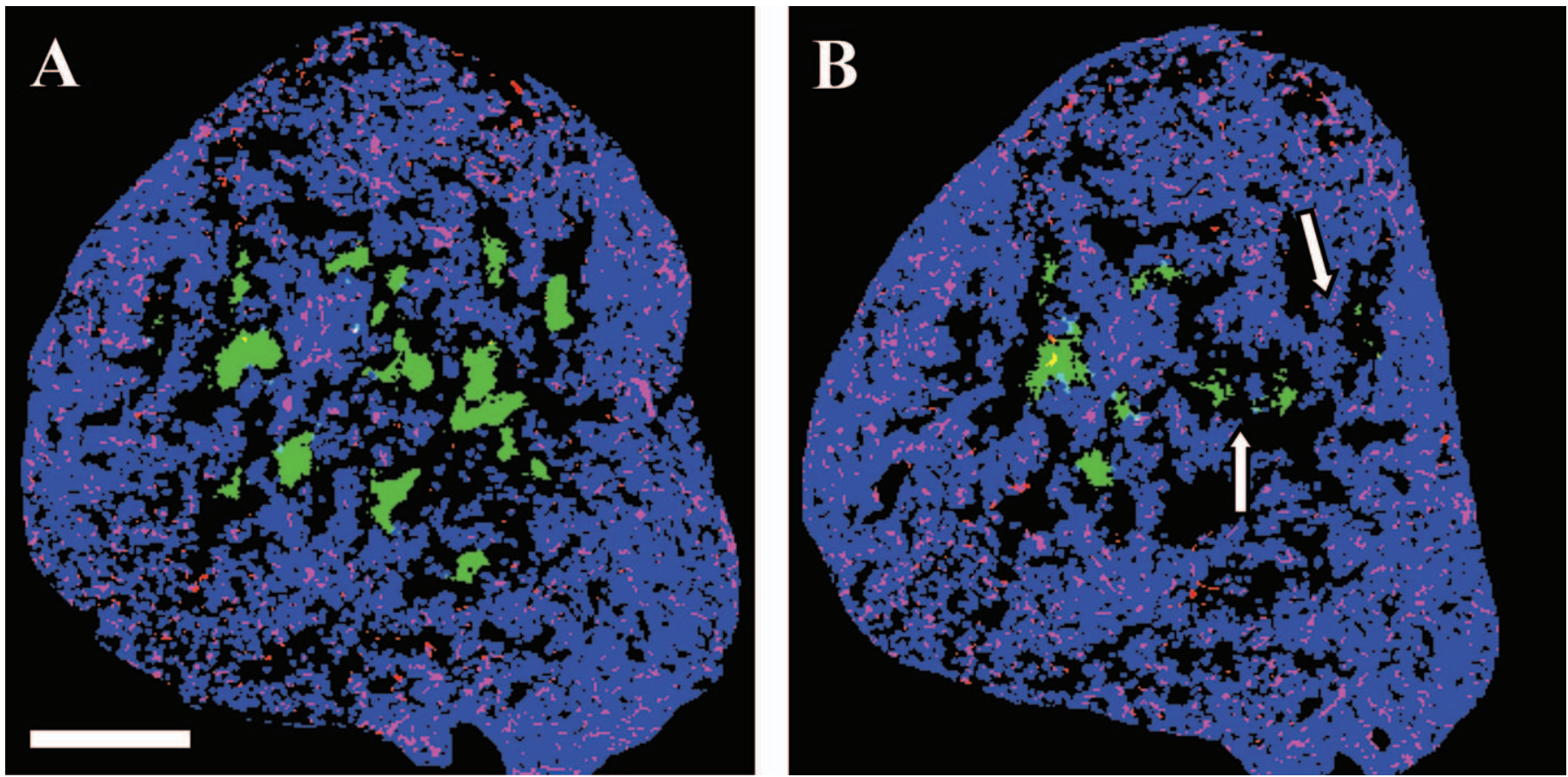

FIG. 3. Composite binary images of consecutive tumor cross sections from the human head and neck squamous cell carcinoma SCCNij3, grown as a xenograft in nude mice, with perfusion marker Hoechst 33342 (blue), vascular endothelium (9F1, red), first hypoxia marker CCI-103F (panel A) and second hypoxia marker pimonidazole (panel B) (both green). There was a good spatial match between the two hypoxia markers in air-breathing control animals. CCI-103F was injected during air breathing (panel A) and acts as reference marker, and pimonidazole was injected during carbogen breathing. The decrease in hypoxia during carbogen breathing was detected with pimonidazole (panel $\mathrm{B}$, arrows) compared to pretreatment levels of hypoxia detected with CCI-103F (panel A). Scale bar is $1 \mathrm{~mm}$. For details, see ref. (154).

between these markers can be exploited. For instance, using pimonidazole as the second marker, it is possible to detect rapid changes in hypoxia since the time between injection and tumor resection can be as short as $30 \mathrm{~min}$ (153). In contrast, when studying the dynamics of hypoxia over longer times, pimonidazole is preferred as the first marker due to its high intracellular stability. With consecutive injection of the clinically approved markers pimonidazole and EF5, the double hypoxia marker assay can be developed to monitor effects of different oxygen-modifying treatments in individual patients. This approach should be explored.

\section{Effects of Oxygen-Modifying Treatments}

Figure 3 shows an example of the double hypoxia marker assay applied in a study on the effect of carbogen breathing in relation to vasculature and blood perfusion in the human squamous cell carcinoma xenograft line SCCNij3. Carbogen breathing resulted in a decrease in hypoxia since there was significantly lower binding of the second hypoxia marker pimonidazole (right) compared to the reference marker CCI-103F (left). The decrease was most pronounced in hypoxic areas near perfused vessels, but in larger perinecrotic areas, there was an evident but not complete decrease in hypoxia (153). These cells were situated beyond the diffusion gradient of oxygen even after hyperoxygenation and were probably also subject to reduced concentrations of nutrients, yet these cells were exposed to the hyp- oxia markers and were still metabolically able to reduce and bind the hypoxia markers. It is likely that these hypoxic cells would die within a short time in unperturbed tumors, but it is a cell population that could become important upon reoxygenation during radiotherapy.

\section{Hypoxic Cell Turnover Rate}

Consecutive injections of the two hypoxia markers pimonidazole and CCI-103F with different intervals have been performed in the murine $\mathrm{C} 38$ colon adenocarcinoma tumor line (Fig. 4). Pimonidazole was given at variable times $(2-120 \mathrm{~h})$ before CCI-103F. The latter was always given $2.5 \mathrm{~h}$ before the animals were killed as reference level of hypoxia at time of analysis. At short times, there was a good spatial co-localization of the two markers. In contrast, at longer times, the first hypoxia marker decreased. This resulted in the appearance of a few cell layers labeled only with the second hypoxia marker at the vessel side of areas that were stained for both hypoxia markers. Cell debris in necrotic areas that was labeled with the first hypoxia marker indicated that the decrease in the first hypoxia marker was caused by death of initially hypoxic cells (154). Those cells were viable and hypoxic at the time of the first marker injection, which resulted in binding, but in the interval between binding and tumor excision, those cells had died and were subject to fragmentation. By calculating a normalized ratio of the hypoxic fractions for the first over the second 
4h, Unirradiated

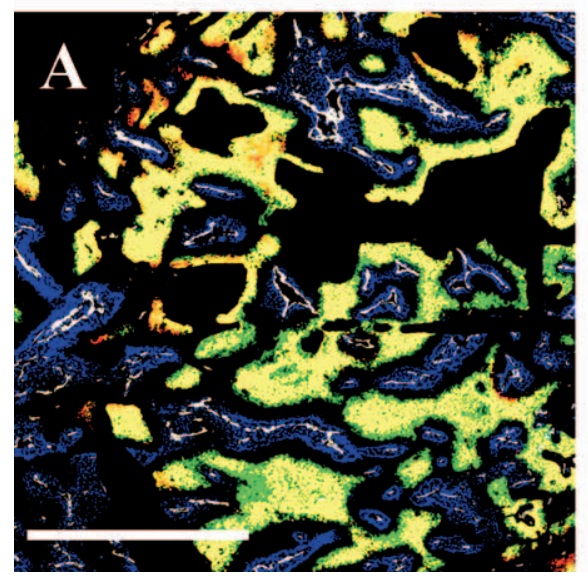

$28 \mathrm{~h}$, Unirradiated

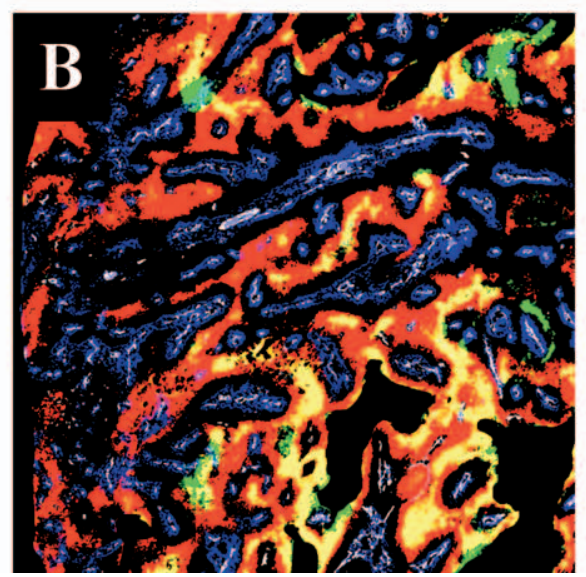

$28 \mathrm{~h}$, Irradiated

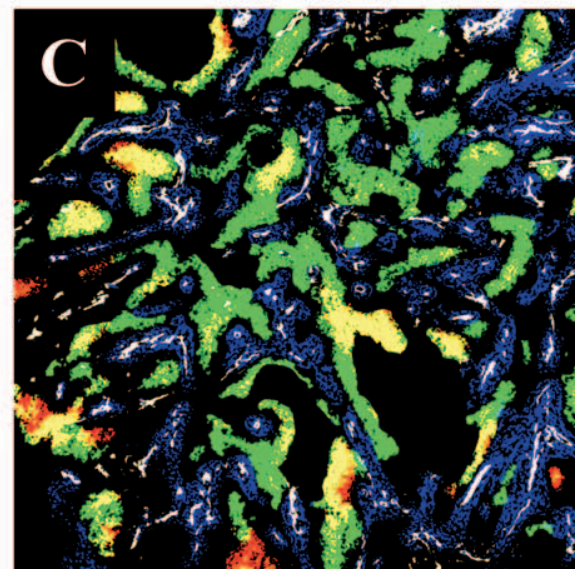

FIG. 4. The murine colon adenocarcinoma C38 tumor with vasculature (9F1, white), the first hypoxia marker pimonidazole (green), and the second

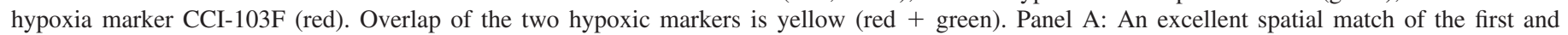

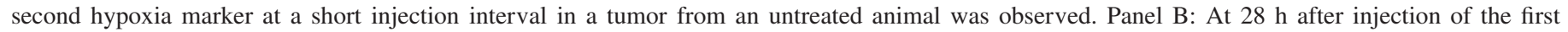

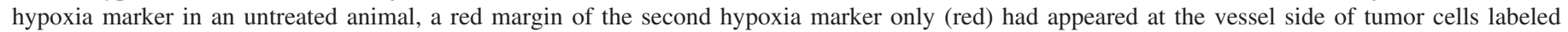

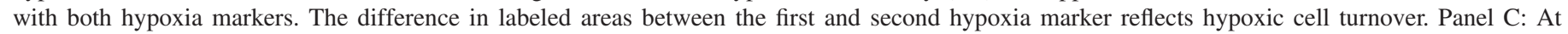

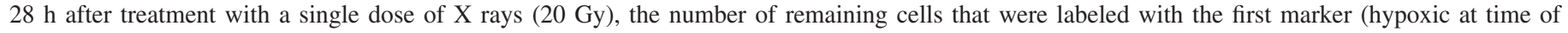

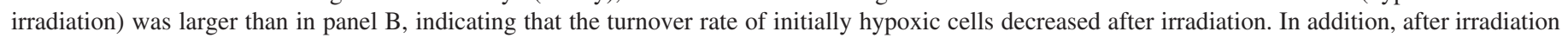

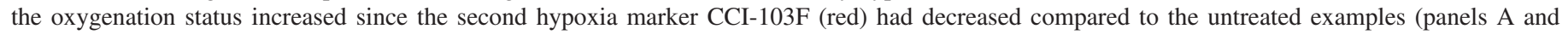
B). Scale bar $=1 \mathrm{~mm}$.

hypoxia marker for a number of times, the half-life of the turnover rate of hypoxic tumor cells was calculated. Among the three different tumor lines that were analyzed in that study, the hypoxic cell turnover rate differed by a factor of three (154). The observed tumor cell line dependence is supported by other studies, which indicate that the life span of hypoxic cells may range from a few hours to several days (147, 193-198). The tumor cell line-dependent differences in hypoxic cell turnover rate and tumor growth illustrate that it is impossible to extrapolate data from a single tumor model to a diverse population of primary tumors. Furthermore, the data indicate that the optimal timing of combined modality treatment schedules can be dependent on the tumor, which should be taken into consideration in the design and interpretation of experimental and clinical studies.

\section{Dynamics of Hypoxic Cells after Irradiation}

The double hypoxia marker assay was also used to study the effect of radiation (20 Gy, single dose) on hypoxia, proliferation and cell death (apoptosis) in the murine C38 tumor line (192). The spatial distribution of the two hypoxia markers at short injection intervals was used as control (Fig. 4A). The first hypoxia marker, pimonidazole, was given $1 \mathrm{~h}$ before treatment to label cells that were hypoxic at the time of irradiation. The second hypoxia marker (CCI$103 \mathrm{~F}$, red) was given at variable times after irradiation and always at a fixed time, $2 \mathrm{~h}$, before tumor excision. Most tumor cells that were hypoxic at time of irradiation had an improved oxygenation status at $8 \mathrm{~h}$ after treatment that remained unchanged over the subsequent $20 \mathrm{~h}$ (Fig. 4C). In addition, it was concluded that radiation caused a signifi- cant decrease in the turnover rate of cells that were hypoxic at the time of irradiation since a larger number of initially hypoxic cells were present in irradiated tumors (Fig. 4C) compared to the untreated tumors (Fig. 4B) (192). This is in agreement with other studies showing that radiation-induced temporary improvements of tumor oxygenation can occur within hours and may last for a few days $(151,199$ 203). Therefore, in many tumors, a radiation-induced improvement in oxygenation status will affect the efficacy of the subsequent dose in a fractionated treatment schedule. It is likely that the kinetics of reoxygenation is affected by intrinsic differences in the turnover rate of hypoxic cells, which may contribute to intertumor heterogeneities in radiation response. In the murine C38 tumor line, the improved oxygenation status after irradiation was interpreted as a decrease in the net cellular respiration resulting from a lower number of proliferating cells and decreased cell density as shown by proliferation and apoptosis markers in combination with the double hypoxia marker assay (192). Although the study was limited to one tumor line, it illustrates the possibility to study multiple parameters in one biopsy or tumor after injection of two hypoxia markers, one proliferation marker and visualization of apoptosis. This assay can also provide information about temporal and spatial changes for different cellular processes and allows interpretation of treatment effects in relation to specific tumor cell populations (192).

Development of this assay for clinical use would provide a means of dynamic measurements of hypoxia during oxygen-modifying treatments such as carbogen breathing and could enable selection of responding and nonresponding 
patients. For the nonresponders, a reduction of unnecessary overtreatment would result in decreased side effects for these patients, allowing selection of another treatment modality that might be more appropriate, for example specifically targeting hypoxic cells, for instance with tirapazamine. The double hypoxia marker assay provides a means to study the effect of novel treatments on the dynamics of hypoxic tumor cells in experimental tumors. If performed on a panel of experimental tumor lines with large differences in the dynamics of hypoxia, this technique can provide a basis for further development of predictive assays and improved design of combined-modality treatments.

\section{SUMMARY}

There is convincing evidence of the clinical importance of tumor hypoxia, but detection of hypoxia is still limited in routine clinical practice. Many investigators have regarded the Eppendorf electrode, which is limited to easily accessible tumors and a few research centers, as a gold standard. However, assays for routine clinical use need to be user friendly and preferable commercially available at reasonable cost. PET- or MR-based noninvasive imaging techniques are potential candidates for routine use, although the poor spatial resolution is a limitation of these methods. These techniques still need to be validated against knowledge of hypoxia at the microscopic level. Bioreductive drugs that label metabolically active hypoxic cells such as pimonidazole and EF5 are appropriate for this purpose, and both pimonidazole and EF5 have potential value for prediction of the treatment outcome. Bioreductive hypoxia markers can be detected with several techniques such as PET and autoradiography and in tumor sections by microscopic imaging techniques. With the latter, hypoxia can be studied in relation to other microenvironmental parameters such as vasculature and proliferation at high spatial resolution. Sequential injection of two different exogenous hypoxia markers in experimental tumors has demonstrated that in tumor sections, spatial and temporal changes in hypoxia can be analyzed in relation to other tumor microenvironmental parameters. This technique can be used for analysis of changes in hypoxia in both treated and untreated tumors and can be applied clinically by means of sequential administration of pimonidazole and EF5.

\section{ACKNOWLEDGMENT}

The Dutch Cancer Society grant number 2003-2901 provided financial support.

Received: June 14, 2006; accepted: August 9, 2006

\section{REFERENCES}

1. P. Vaupel, Tumor microenvironmental physiology and its implications for radiation oncology. Semin. Radiat. Oncol. 14, 198-206
(2004).

2. Q. T. Le, N. C. Denko and A. J. Giaccia, Hypoxic gene expression and metastasis. Cancer Metastasis Rev. 23, 293-310 (2004).

3. M. Höckel and P. Vaupel, Tumor hypoxia: Definitions and current clinical, biologic, and molecular aspects. J. Natl. Cancer Inst. 93 266-276 (2001).

4. E. K. Rofstad, Microenvironment-induced cancer metastasis. Int. J. Radiat. Biol. 76, 589-605 (2000).

5. A. L. Harris, Hypoxia-a key regulatory factor in tumour growth. Nat. Rev. Cancer 2, 38-47 (2002).

6. D. M. Brizel, S. P. Scully, J. M. Harrelson, L. J. Layfield, J. M. Bean, L. R. Prosnitz and M. W. Dewhirst, Tumor oxygenation predicts for the likelihood of distant metastases in human soft tissue sarcoma. Cancer Res. 56, 941-943 (1996).

7. J. C. Mottram, A factor of importance in the radiosensitivity of tumours. Br. J. Radiol. 9, 606-614 (1936).

8. L. Gray, A. D. Conger, M. Ebert, S. Hornsey and O. C. A. Scott, The concentration of oxygen dissolved in tissues at the time of irradiation as a factor in radiotherapy. Br. J. Radiol. 28, 638-648 (1953).

9. D. M. Brizel, G. S. Sibley, L. R. Prosnitz, R. L. Scher and M. W. Dewhirst, Tumor hypoxia adversely affects the prognosis of carcinoma of the head and neck. Int. J. Radiat. Oncol. Biol. Phys. 38, 285-289 (1997).

10. A. Fyles, M. Milosevic, D. Hedley, M. Pintilie, W. Levin, L. Manchul and R. P. Hill, Tumor hypoxia has independent predictor impact only in patients with node-negative cervix cancer. J. Clin. Oncol. 20, 680-687 (2002).

11. M. Höckel, K. Schlenger, B. Aral, M. Mitze, U. Schaffer and P. Vaupel, Association between tumor hypoxia and malignant progression in advanced cancer of the uterine cervix. Cancer Res. 56, 4509-4515 (1996).

12. J. H. A. M. Kaanders, K. I. E. M. Wijffels, H. A. M. Marres, A. S. E. Ljungkvist, L. A. M. Pop, F. J. A. van den Hoogen, P. C. M. de Wilde, J. Bussink, J. A. Raleigh and A. J. van der Kogel, Pimonidazole binding and tumor vascularity predict for treatment outcome in head and neck cancer. Cancer Res. 62, 7066-7074 (2002).

13. J. Overgaard, H. S. Hansen, M. Overgaard, L. Bastholt, A. Berthelsen, L. Specht, B. Lindelov and K. Jorgensen, A randomized double-blind phase III study of nimorazole as a hypoxic radiosensitizer of primary radiotherapy in supraglottic larynx and pharynx carcinoma. Results of the Danish Head and Neck Cancer Study (DAHANCA) Protocol 5-85. Radiother. Oncol. 46, 135-146 (1998).

14. D. J. Chaplin, M. R. Horsman and M. J. Trotter, Effect of nicotinamide on the microregional heterogeneity of oxygen delivery within a murine tumor. J. Natl. Cancer Inst. 82, 672-676 (1990).

15. J. M. Henk and C. W. Smith, Radiotherapy and hyperbaric oxygen in head and neck cancer. Interim report of second clinical trial. Lancet 2, 104-105 (1977).

16. J. H. A. M. Kaanders, L. A. M. Pop, H. A. M. Marres, J. Liefers, F. J. van den Hoogen, W. A. van Daal and A. J. van der Kogel, Accelerated radiotherapy with carbogen and nicotinamide (ARCON) for laryngeal cancer. Radiother. Oncol. 48, 115-122 (1998).

17. R. Mayer, M. R. Hamilton-Farrell, A. J. van der Kleij, J. Schmutz, G. Granstrom, Z. Sicko, Y. Melamed, U. M. Carl, K. A. Hartmann and P. Sminia, Hyperbaric oxygen and radiotherapy. Strahlenther. Onkol. 181, 113-123 (2005).

18. Y. Shi, C. S. Lee, J. Wu, C. J. Koch, S. R. Thom, A. Maity and E. J. Bernhard, Effects of hyperbaric oxygen exposure on experimental head and neck tumor growth, oxygenation, and vasculature. Head Neck 27, 362-369 (2005).

19. A. Rosenberg and S. Knox, Radiation sensitization with redox modulators: A promising approach. Int. J. Radiat. Oncol. Biol. Phys. 64, 343-354 (2006).

20. E. M. Zeman, J. M. Brown, M. J. Lemmon, V. K. Hirst and W. W. Lee, SR-4233: a new bioreductive agent with high selective toxicity for hypoxic mammalian cells. Int. J. Radiat. Oncol. Biol. Phys. 12, 1239-1242 (1986).

21. J. Overgaard and M. R. Horsman, Modification of hypoxia-induced 
radioresistance in tumors by the use of oxygen and sensitizers. Semin. Radiat. Oncol. 6, 10-21 (1996).

22. I. F. Tannock, The relation between cell proliferation and the vascular system in a transplanted mouse mammary tumour. Br. J. Cancer 22, 258-273 (1968).

23. D. G. Hirst and J. Denekamp, Tumour cell proliferation in relation to the vasculature. Cell. Tissue. Kinet. 12, 31-42 (1979).

24. J. Bussink, J. H. A. M. Kaanders, P. F. J. W. Rijken, C. A. Martindale and A. J. van der Kogel, Multiparameter analysis of vasculature, perfusion and proliferation in human tumour xenografts. $\mathrm{Br}$. J. Cancer 77, 57-64 (1998).

25. A. S. E. Ljungkvist, J. Bussink, P. F. J. W. Rijken, J. H. A. M. Kaanders, A. J. van der Kogel and J. Denekamp, Vascular architecture, hypoxia, and proliferation in first-generation xenografts of human head-and-neck squamous cell carcinomas. Int. J. Radiat. Oncol. Biol. Phys. 54, 215-228 (2002).

26. M. A. Konerding, C. van Ackern, E. Fait, F. Steinberg and C. Streffer, Morphological aspects of tumor angiogenseis and microcirculation. In Blood Perfusion and Microenvironmnet of Human Tumors (M. Molls and P. Vaupel, Eds.), pp. 6-17. Springer Verlag, Berlin and Heidelberg, 1998.

27. H. J. J. A. Bernsen, P. F. J. W. Rijken, T. Oostendorp and A. J. van der Kogel, Vascularity and perfusion of human gliomas xenografted in the athymic nude mouse. Br. J. Cancer 71, 721-726 (1995).

28. N. Weidner, J. P. Semple, W. R. Welch and J. Folkman, Tumor angiogenesis and metastasis-correlation in invasive breast carcinoma. N. Engl. J. Med. 324, 1-8 (1991).

29. J. Bussink, J. H. Kaanders and A. J. van der Kogel, Tumor hypoxia at the micro-regional level: Clinical relevance and predictive value of exogenous and endogenous hypoxic cell markers. Radiother. Oncol. 67, 3-15 (2003).

30. R. H. Thomlinson and L. H. Gray, The histological structure of some human lung cancers and the possible implications for radiotherapy. Br. J. Cancer IX, 539-549 (1955).

31. J. M. Cline, D. E. Thrall, G. L. Rosner and J. A. Raleigh, Distribution of the hypoxia marker CCI-103F in canine tumors. Int. J. Radiat. Oncol. Biol. Phys. 28, 921-933 (1994).

32. P. Vaupel, F. Kallinowski and P. Okunieff, Blood flow, oxygen and nutrient supply, and metabolic microenvironment of human tumors: a review. Cancer Res. 49, 6449-6465 (1989).

33. K. I. E. M. Wijffels, J. H. A. M. Kaanders, P. F. J. W. Rijken, J. Bussink, F. J. van den Hoogen, H. A. M. Marres, P. C. M. de Wilde, J. A. Raleigh and A. J. van der Kogel, Vascular architecture and hypoxic profiles in human head and neck squamous cell carcinomas. Br. J. Cancer 83, 674-683 (2000).

34. S. M. Evans, S. M. Hahn, D. P. Magarelli and C. J. Koch, Hypoxic heterogeneity in human tumors: EF5 binding, vasculature, necrosis, and proliferation. Am. J. Clin. Oncol. 24, 467-472 (2001).

35. E. M. Zeman, D. P. Calkins, J. M. Cline, D. E. Thrall and J. A. Raleigh, The relationship between proliferative and oxygenation status in spontaneous canine tumors. Int. J. Radiat. Oncol. Biol. Phys. 27, 891-898 (1993)

36. H. S. Reinhold, B. Blachiwiecz and A. Blok, Oxygenation and reoxygenation in "sandwich" tumours. Bibl. Anat. 15, 270-272 (1977).

37. J. M. Brown, Evidence for acutely hypoxic cells in mouse tumours, and a possible mechanism of reoxygenation. Br. J. Radiol. 52, 650656 (1979).

38. M. J. Trotter, D. J. Chaplin, R. E. Durand and P. L. Olive, The use of fluorescent probes to identify regions of transient perfusion in murine tumors. Int. J. Radiat. Oncol. Biol. Phys. 16, 931-934 (1989).

39. R. E. Durand and N. E. LePard, Contribution of transient blood flow to tumour hypoxia in mice. Acta Oncol. 34, 317-323 (1995).

40. R. E. Durand and N. E. LePard, Tumour blood flow influences combined radiation and doxorubicin treatments. Radiother. Oncol. 42, 171-179 (1997).

41. D. J. Chaplin, R. E. Durand and P. L. Olive, Acute hypoxia in tumors: Implications for modifiers of radiation effects. Int. J. Radiat. Oncol. Biol. Phys. 12, 1279-1282 (1986).

42. M. W. Dewhirst, H. Kimura, S. W. Rehmus, R. D. Braun, D. Papahadjopoulos, K. Hong and T. W. Secomb, Microvascular studies on the origins of perfusion-limited hypoxia. Br. J. Cancer 27 (Suppl.), S247-S251 (1996).

43. M. W. Dewhirst, E. T. Ong, R. D. Braun, B. Smith, B. Klitzman, S. M. Evans and D. Wilson, Quantification of longitudinal tissue $p \mathrm{O}_{2}$ gradients in window chamber tumours: impact on tumour hypoxia. Br. J. Cancer 79, 1717-1722 (1999).

44. S. Walenta, S. Snyder, Z. A. Haroon, R. D. Braun, K. Amin, D. Brizel, W. Mueller-Klieser, B. Chance and M. W. Dewhirst, Tissue gradients of energy metabolites mirror oxygen tension gradients in a rat mammary carcinoma model. Int. J. Radiat. Oncol. Biol. Phys. 51, 840-848 (2001).

45. B. G. Wouters, S. A. Weppler, M. Koritzinsky, W. Landuyt, S. Nuyts, J. Theys, R. K. Chiu and P. Lambin, Hypoxia as a target for combined modality treatments. Eur. J. Cancer 38, 240-257 (2002).

46. M. Milosevic, A. Fyles, D. Hedley and R. Hill, The human tumor microenvironment: Invasive (needle) measurement of oxygen and interstitial fluid pressure. Semin. Radiat. Oncol. 14, 249-258 (2004).

47. D. M. Brizel, R. K. Dodge, R. W. Clough and M. W. Dewhirst, Oxygenation of head and neck cancer: Changes during radiotherapy and impact on treatment outcome. Radiother. Oncol. 53, 113-117 (1999).

48. M. Nordsmark, S. M. Bentzen, V. Rudat, D. Brizel, E. Lartigau, P. Stadler, A. Becker, M. Adam, M. Molls and J. Overgaard, Prognostic value of tumor oxygenation in 397 head and neck tumors after primary radiation therapy. An international multi-center study. Radiother. Oncol. 77, 18-24 (2005).

49. S. M. Evans, D. Fraker, S. M. Hahn, K. Gleason, W. T. Jenkins, K. Jenkins, W. T. Hwang, P. Zhang, R. Mick and C. J. Koch, EF5 binding and clinical outcome in human soft tissue sarcomas. Int. J. Radiat. Oncol. Biol. Phys. 64, 922-927 (2006).

50. P. L. Olive, J. P. Banath and C. Aquino-Parsons, Measuring hypoxia in solid tumours-is there a gold standard? Acta Oncol. 40, 917923 (2001).

51. J. Bussink, J. H. A. M. Kaanders and A. J. van der Kogel, Tumor hypoxia at the micro-regional level: Clinical relevance and predictive value of exogenous and endogenous hypoxic cell markers. $\mathrm{Ra}$ diother. Oncol. 67, 3-15 (2003).

52. J. A. Raleigh, M. W. Dewhirst and D. E. Thrall, Measuring tumor hypoxia. Semin. Radiat. Oncol. 6, 37-45 (1996).

53. P. L. Olive and R. E. Durand, Detection of hypoxic cells in a murine tumor with the use of the comet assay. J. Natl. Cancer Inst. 84, 707-711 (1992)

54. J. E. Moulder and S. Rockwell, Hypoxic fractions of solid tumors: Experimental techniques, methods of analysis, and a survey of existing data. Int. J. Radiat. Oncol. Biol. Phys. 10, 695-712 (1984).

55. M. R. Horsman, A. A. Khalil, D. W. Siemann, C. Grau, S. A. Hill, E. M. Lynch, D. J. Chaplin and J. Overgaard, Relationship between radiobiological hypoxia in tumors and electrode measurements of tumor oxygenation. Int. J. Radiat. Oncol. Biol. Phys. 29, 439-442 (1994).

56. I. Papandreou, A. Powell, A. L. Lim and N. Denko, Cellular reaction to hypoxia: sensing and responding to an adverse environment. Mutat. Res. 569, 87-100 (2005).

57. R. A. Gatenby, H. B. Kessler, J. S. Rosenblum, L. R. Coia, P. J. Moldofsky, W. H. Hartz and G. J. Broder, Oxygen distribution in squamous cell carcinoma metastases and its relationship to outcome of radiation therapy. Int. J. Radiat. Oncol. Biol. Phys. 14, 831-838 (1988).

58. P. Vaupel, K. Schlenger, C. Knoop and M. Höckel, Oxygenation of human tumors: Evaluation of tissue oxygen distribution in breast cancers by computerized $\mathrm{O}_{2}$ tension measurements. Cancer Res. 51, 3316-3322 (1991).

59. J. Bussink, J. H. A. M. Kaanders, A. M. Strik and A. J. van der Kogel, Effects of nicotinamide and carbogen on oxygenation in hu- 
man tumor xenografts measured with luminescence-based fiber optic probes. Radiother. Oncol. 57, 21-30 (2000).

60. K. G. Brurberg, B. A. Graff, D. R. Olsen and E. K. Rofstad, Tumorline specific $p \mathrm{O}_{2}$ fluctuations in human melanoma xenografts. Int. J. Radiat. Oncol. Biol. Phys. 58, 403-409 (2004).

61. D. R. Collingridge, W. K. Young, B. Vojnovic, P. Wardman, E. M. Lynch, S. A. Hill and D. J. Chaplin, Measurement of tumor oxygenation: A comparison between polarographic needle electrodes and a time-resolved luminescence-based optical sensor. Radiat. Res. 147, 329-334 (1997).

62. B. M. Seddon, D. J. Honess, B. Vojnovic, G. M. Tozer and P. Workman, Measurement of tumor oxygenation: In vivo comparison of a luminescence fiber-optic sensor and a polarographic electrode in the p22 tumor. Radiat. Res. 155, 837-846 (2001).

63. M. Höckel, C. Knoop, K. Schlenger, B. Vorndran, E. Baussmann, M. Mitze, P. G. Knapstein and P. Vaupel, Intratumoral $p \mathrm{O}_{2}$ predicts survival in advanced cancer of the uterine cervix. Radiother. Oncol. 26, 45-50 (1993).

64. W. K. Young, B. Vojnovic and P. Wardman, Measurement of oxygen tension in tumours by time-resolved fluorescence. Br. J. Cancer 27 (Suppl.), S256-S259 (1996).

65. J. Bussink, J. H. A. M. Kaanders, A. M. Strik, B. Vojnovic and A. J. van der Kogel, Optical sensor-based oxygen tension measurements correspond with hypoxia marker binding in three human tumor xenograft lines. Radiat. Res. 154, 547-555 (2000).

66. T. Jarm, G. Sersa and D. Miklavcic, Oxygenation and blood flow in tumors treated with hydralazine: Evaluation with a novel luminescence-based fiber-optic sensor. Technol. Health Care 10, 363 380 (2002).

67. S. M. Evans, K. D. Judy, I. Dunphy, W. T. Jenkins, P. T. Nelson, R. Collins, E. P. Wileyto, K. Jenkins, S. M. Hahn and C. J. Koch, Comparative measurements of hypoxia in human brain tumors using needle electrodes and EF5 binding. Cancer Res. 64, 1886-1892 (2004).

68. S. S. Foo, D. F. Abbott, N. Lawrentschuk and A. M. Scott, Functional imaging of intratumoral hypoxia. Mol. Imaging Biol. 6, 291305 (2004).

69. B. Gallez, C. Baudelet and B. F. Jordan, Assessment of tumor oxygenation by electron paramagnetic resonance: Principles and applications. NMR Biomed. 17, 240-262 (2004).

70. F. Goda, J. A. O’Hara, E. S. Rhodes, K. J. Liu, J. F. Dunn, G. Bacic and H. M. Swartz, Changes of oxygen tension in experimental tumors after a single dose of X-ray irradiation. Cancer Res. 55, 22492252 (1995).

71. G. Y. Jin, S. J. Li, J. E. Moulder and J. A. Raleigh, Dynamic measurements of hexafluoromisonidazole (CCI-103F) retention in mouse tumours by ${ }^{1} \mathrm{H} /{ }^{19} \mathrm{~F}$ magnetic resonance spectroscopy. Int. J. Radiat. Biol. 58, 1025-1034 (1990).

72. L. Kwock, M. Gill, H. L. McMurry, W. Beckman, J. A. Raleigh and A. P. Joseph, Evaluation of a fluorinated 2-nitroimidazole binding to hypoxic cells in tumor-bearing rats by ${ }^{19} \mathrm{~F}$ magnetic resonance spectroscopy and immunohistochemistry. Radiat. Res. 129, 71-78 (1992).

73. S. P. Robinson, F. A. Howe, M. Stubbs and J. R. Griffiths, Effects of nicotinamide and carbogen on tumour oxygenation, blood flow, energetics and blood glucose levels. Br. J. Cancer 82, 2007-2014 (2000).

74. R. P. Mason, P. P. Antich, E. E. Babcock, A. Constantinescu, P. Peschke and E. W. Hahn, Non-invasive determination of tumor oxygen tension and local variation with growth. Int. J. Radiat. Oncol. Biol. Phys. 29, 95-103 (1994).

75. W. Landuyt, R. Hermans, H. Bosmans, S. Sunaert, E. Beatse, D. Farina, M. Meijerink, H. Zhang, W. van Den Bogaert and G. Marchal, BOLD contrast fMRI of whole rodent tumour during air or carbogen breathing using echo-planar imaging at 1.5 T. Eur. Radiol. 11, 2332-2340 (2001).

76. J. F. Dunn, J. A. O'Hara, Y. Zaim-Wadghiri, H. Lei, M. E. Meyerand, O. Y. Grinberg, H. Hou, P. J. Hoopes, E. Demidenko and H. M. Swartz, Changes in oxygenation of intracranial tumors with carbo- gen: A BOLD MRI and EPR oximetry study. J. Magn. Reson. Imaging 16, 511-521 (2002).

77. B. B. Williams, H. al Hallaq, G. V. Chandramouli, E. D. Barth, J. N. Rivers, M. Lewis, V. E. Galtsev, G. S. Karczmar and H. J. Halpern, Imaging spin probe distribution in the tumor of a living mouse with $250 \mathrm{MHz}$ EPR: Correlation with BOLD MRI. Magn. Reson. Imaging 47, 634-638 (2002).

78. B. F. Jordan, P. Misson, R. Demeure, C. Baudelet, N. Beghein and B. Gallez, Changes in tumor oxygenation/perfusion induced by the no donor, isosorbide dinitrate, in comparison with carbogen: Monitoring by EPR and MRI. Int. J. Radiat. Oncol. Biol. Phys. 48, 565570 (2000).

79. P. Mahy, M. De Bast, B. Gallez, J. Gueulette, C. J. Koch, P. Scalliet and V. Gregoire, In vivo colocalization of 2-nitroimidazole EF5 fluorescence intensity and electron paramagnetic resonance oximetry in mouse tumors. Radiother. Oncol. 67, 53-61 (2003).

80. N. M. Mazure, M. C. Brahimi-Horn, M. A. Berta, E. Benizri, R. L. Bilton, F. Dayan, A. Ginouves, E. Berra and J. Pouyssegur, HIF-1: master and commander of the hypoxic world. A pharmacological approach to its regulation by siRNAs. Biochem. Pharmacol. 68, 971-980 (2004).

81. H. Pilch, K. Schlenger, E. Steiner, P. Brockerhoff, P. Knapstein and P. Vaupel, Hypoxia-stimulated expression of angiogenic growth factors in cervical cancer cells and cervical cancer-derived fibroblasts. Int. J. Gynecol. Cancer 11, 137-142 (2001).

82. R. S. Kerbel, A. Viloria Petit, F. Okada and J. Rak, Establishing a link between oncogenes and tumor angiogenesis. Mol. Med. 4, 286295 (1998).

83. M. Höckel and P. Vaupel, Biological consequences of tumor hypoxia. Semin. Oncol. 28 (Suppl. 8), 36-41 (2001).

84. P. H. Maxwell, HIF-1's relationship to oxygen: simple yet sophisticated. Cell Cycle 3, 156-159 (2004).

85. P. Vaupel, The role of hypoxia-induced factors in tumor progression. Oncologist 9 (Suppl. 5), 10-17 (2004).

86. G. L. Semenza, Hypoxia, clonal selection, and the role of HIF-1 in tumor progression. Crit. Rev. Biochem. Mol. Biol. 35, 71-103 (2000).

87. G. L. Semenza, Targeting HIF-1 for cancer therapy. Nat. Rev. Cancer 3, 721-732 (2003).

88. C. W. Pugh and P. J. Ratcliffe, Regulation of angiogenesis by hypoxia: role of the HIF system. Nat. Med. 9, 677-684 (2003).

89. P. Carmeliet, Y. Dor, J. M. Herbert, D. Fukumura, K. Brusselmans, M. Dewerchin, M. Neeman, F. Bono, R. Abramovitch and E. Keshet, Role of HIF- $1 \alpha$ in hypoxia-mediated apoptosis, cell proliferation and tumour angiogenesis. Nature 394, 485-490 (1998).

90. C. C. Wykoff, N. J. P. Beasley, P. H. Watson, K. J. Turner, J. Pastorek, A. Sibtain, G. D. Wilson, H. Turley, K. L. Talks and A. L. Harris, Hypoxia-inducible expression of tumor-associated carbonic anhydrases. Cancer Res. 60, 7075-7083 (2000).

91. K. L. Talks, H. Turley, K. C. Gatter, P. H. Maxwell, C. W. Pugh, P. J. Ratcliffe and A. L. Harris, The expression and distribution of the hypoxia-inducible factors HIF-1 and HIF- $2 \alpha$ in normal human tissues, cancers, and tumor-associated macrophages. Am. J. Pathol. 157, 411-421 (2000).

92. H. Zhong, A. M. De Marzo, E. Laughner, M. Lim, D. A. Hilton, D. Zagzag, P. Buechler, W. B. Isaacs, G. L. Semenza and J. W. Simons, Overexpression of hypoxia-inducible factor $1 \alpha$ in common human cancers and their metastases. Cancer Res. 59, 5830-5835 (1999)

93. M. I. Koukourakis, A. Giatromanolaki, E. Sivridis, C. Simopoulos, H. Turley, K. Talks, K. C. Gatter and A. L. Harris, Hypoxia-inducible factor (HIF1A and HIF2A), angiogenesis, and chemoradiotherapy outcome of squamous cell head-and-neck cancer. Int. J. Radiat. Oncol. Biol. Phys. 53, 1192-1202 (2002).

94. D. M. Aebersold, P. Burri, K. T. Beer, J. Laissue, V. Djonov, R. H. Greiner and G. L. Semenza, Expression of hypoxia-inducible factor$1 \alpha$ : A novel predictive and prognostic parameter in the radiotherapy of oropharyngeal cancer. Cancer Res. 61, 2911-2916 (2001). 
95. P. Birner, B. Gatterbauer, G. Oberhuber, M. Schindl, K. Rossler, A. Prodinger, H. Budka and J. A. Hainfellner, Expression of hypoxiainducible factor- $1 \alpha$ in oligodendrogliomas: Its impact on prognosis and on neoangiogenesis. Cancer 92, 165-171 (2001).

96. D. Vordermark and J. M. Brown, Endogenous markers of tumor hypoxia predictors of clinical radiation resistance? Strahlenther. Onkol. 179, 801-811 (2003).

97. N. J. Beasley, R. Leek, M. Alam, H. Turley, G. J. Cox, K. Gatter, P. Millard, S. Fuggle and A. L. Harris, Hypoxia-inducible factors HIF- $1 \alpha$ and HIF- $2 \alpha$ in head and neck cancer: Relationship to tumor biology and treatment outcome in surgically resected patients. Cancer Res. 62, 2493-2497 (2002).

98. V. Vukovic, H. K. Haugland, T. Nicklee, A. J. Morrison and D. W. Hedley, Hypoxia-inducible factor- $1 \alpha$ is an intrinsic marker for hypoxia in cervical cancer xenografts. Cancer Res. 61, 7394-7398 (2001).

99. D. Vordermark and J. M. Brown, Evaluation of hypoxia-inducible factor-1 $\alpha$ (HIF-1 $\alpha)$ as an intrinsic marker of tumor hypoxia in U87 MG human glioblastoma: In vitro and xenograft studies. Int. J. Radiat. Oncol. Biol. Phys. 56, 1184-1193 (2003).

100. H. L. Janssen, K. M. Haustermans, D. Sprong, G. Blommestijn, I. Hofland, F. J. Hoebers, E. Blijweert, J. A. Raleigh, G. L. Semenza and A. C. Begg, HIF-1A, pimonidazole, and iododeoxyuridine to estimate hypoxia and perfusion in human head-and-neck tumors. Int. J. Radiat. Oncol. Biol. Phys. 54, 1537-1549 (2002).

101. R. E. Airley, J. Loncaster, J. A. Raleigh, A. L. Harris, S. E. Davidson, R. D. Hunter, C. M. West and I. J. Stratford, GLUT-1 and CAIX as intrinsic markers of hypoxia in carcinoma of the cervix: Relationship to pimonidazole binding. Int. J. Cancer 104, 85-91 (2003).

102. E. G. Troost, J. Bussink, J. H. Kaanders, J. van Eerd, J. P. Peters, P. F. Rijken, O. C. Boerman and A. J. van der Kogel, Comparison of different methods of CAIX quantification in relation to hypoxia in three human head and neck tumor lines. Radiother. Oncol. 76, 194-199 (2005)

103. B. Jankovic, C. Aquino-Parsons, J. A. Raleigh, E. J. Stanbridge, R. E. Durand, J. P. Banath, S. H. MacPhail and P. L. Olive, Comparison between pimonidazole binding, oxygen electrode measurements, and expression of endogenous hypoxia markers in cancer of the uterine cervix. Cytometry B Clin. Cytom. 70, 45-55 (2006).

104. P. L. Olive, C. Aquino-Parsons, S. H. MacPhail, S. Y. Liao, J. A. Raleigh, M. I. Lerman and E. J. Stanbridge, Carbonic anhydrase 9 as an endogenous marker for hypoxic cells in cervical cancer. Cancer Res. 61, 8924-8929 (2001).

105. D. Vordermark, A. Kaffer, S. Riedl, A. Katzer and M. Flentje, Characterization of carbonic anhydrase IX (CA IX) as an endogenous marker of chronic hypoxia in live human tumor cells. Int. J. Radiat. Oncol. Biol. Phys. 61, 1197-1207 (2005).

106. K. J. Turner, J. P. Crew, C. C. Wykoff, P. H. Watson, R. Poulsom, J. Pastorek, P. J. Ratcliffe, D. Cranston and A. L. Harris, The hypoxia-inducible genes VEGF and CA9 are differentially regulated in superficial vs invasive bladder cancer. Br. J. Cancer 86, 1276-1282 (2002).

107. M. Rafajova, M. Zatovicova, R. Kettmann, J. Pastorek and S. Pastorekova, Induction by hypoxia combined with low glucose or low bicarbonate and high posttranslational stability upon reoxygenation contribute to carbonic anhydrase IX expression in cancer cells. Int J. Oncol. 24, 995-1004 (2004).

108. B. S. Sorensen, J. Hao, J. Overgaard, H. Vorum, B. Honore, J. Alsner and M. R. Horsman, Influence of oxygen concentration and $\mathrm{pH}$ on expression of hypoxia induced genes. Radiother. Oncol. 76, 187-193 (2005).

109. J. A. Loncaster, A. L. Harris, S. E. Davidson, J. P. Logue, R. D. Hunter, C. C. Wycoff, J. Pastorek, P. J. Ratcliffe, I. J. Stratford and C. M. West, Carbonic anhydrase (CA IX) expression, a potential new intrinsic marker of hypoxia: Correlations with tumor oxygen measurements and prognosis in locally advanced carcinoma of the cervix. Cancer Res. 61, 6394-6399 (2001).

110. M. I. Koukourakis, A. Giatromanolaki, E. Sivridis, K. Simopoulos, J. Pastorek, C. C. Wykoff, K. C. Gatter and A. L. Harris, Hypoxiaregulated carbonic anhydrase-9 (CA9) relates to poor vasculariza- tion and resistance of squamous cell head and neck cancer to chemoradiotherapy. Clin. Cancer Res. 7, 3399-3403 (2001).

111. D. Hedley, M. Pintilie, J. Woo, A. Morrison, D. Birle, A. Fyles, M. Milosevic and R. Hill, Carbonic anhydrase IX expression, hypoxia, and prognosis in patients with uterine cervical carcinomas. Clin. Cancer Res. 9, 5666-5674 (2003).

112. R. A. Jonathan, K. I. Wijffels, W. Peeters, P. C. de Wilde, H. A. Marres, M. A. Merkx, E. Oosterwijk, A. J. van der Kogel and J. H. Kaanders, The prognostic value of endogenous hypoxia-related markers for head and neck squamous cell carcinomas treated with ARCON. Radiother. Oncol. 79, 288-297 (2006).

113. N. V. Iyer, L. E. Kotch, F. Agani, S. W. Leung, E. Laughner, R. H. Wenger, M. Gassmann, J. D. Gearhart, A. M. Lawler and G. L. Semenza, Cellular and developmental control of $\mathrm{O}_{2}$ homeostasis by hypoxia-inducible factor $1 \alpha$. Genes Dev. 12, 149-162 (1998).

114. M. Younes, D. Juarez, L. V. Lechago and S. P. Lerner, Glut 1 expression in transitional cell carcinoma of the urinary bladder is associated with poor patient survival. Anticancer Res. 21, 575-578 (2001).

115. M. Younes, R. W. Brown, M. Stephenson, M. Gondo and P. T. Cagle, Overexpression of Glut1 and Glut3 in stage I nonsmall cell lung carcinoma is associated with poor survival. Cancer 80, 10461051 (1997).

116. R. S. Brown and R. L. Wahl, Overexpression of Glut-1 glucose transporter in human breast cancer. An immunohistochemical study. Cancer 72, 2979-2985 (1993).

117. P. Mellanen, H. Minn, R. Grenman and P. Harkonen, Expression of glucose transporters in head-and-neck tumors. Int. J. Cancer $\mathbf{5 6}$, 622-629 (1994).

118. M. Younes, L. V. Lechago, J. R. Somoano, M. Mosharaf and J. Lechago, Wide expression of the human erythrocyte glucose transporter Glut1 in human cancers. Cancer Res. 56, 1164-1167 (1996).

119. R. S. Haber, A. Rathan, K. R. Weiser, A. Pritsker, S. H. Itzkowitz, C. Bodian, G. Slater, A. Weiss and D. E. Burstein, GLUT1 glucose transporter expression in colorectal carcinoma: A marker for poor prognosis. Cancer 83, 34-40 (1998).

120. R. Airley, J. Loncaster, S. Davidson, M. Bromley, S. Roberts, A. Patterson, R. Hunter, I. Stratford and C. West, Glucose transporter glut-1 expression correlates with tumor hypoxia and predicts metastasis-free survival in advanced carcinoma of the cervix. Clin. Cancer Res. 7, 928-934 (2001).

121. R. J. Oliver, R. T. Woodwards, P. Sloan, N. S. Thakker, I. J. Stratford and R. E. Airley, Prognostic value of facilitative glucose transporter Glut-1 in oral squamous cell carcinomas treated by surgical resection; Results of EORTC Translational Research Fund studies. Eur. J. Cancer 40, 503-507 (2004).

122. A. Mayer, M. Hockel, A. Wree and P. Vaupel, Microregional expression of glucose transporter-1 and oxygenation status: Lack of correlation in locally advanced cervical cancers. Clin. Cancer Res. 11, 2768-2773 (2005).

123. H. Mineta, K. Miura, S. Takebayashi, K. Misawa, K. Araki, Y. Misawa and Y. Ueda, Prognostic value of glucose transporter 1 expression in patients with hypopharyngeal carcinoma. Anticancer Res. 22, 3489-3494 (2002).

124. Y. Chen, G. Shi, W. Xia, C. Kong, S. Zhao, A. F. Gaw, E. Y. Chen, G. P. Yang, A. J. Giaccia and A. C. Koong, Identification of hypoxia-regulated proteins in head and neck cancer by proteomic and tissue array profiling. Cancer Res. 64, 7302-7310 (2004).

125. S. C. Chou, Y. Azuma, M. A. Varia and J. A. Raleigh, Evidence that involucrin, a marker for differentiation, is oxygen regulated in human squamous cell carcinomas. Br. J. Cancer 90, 728-735 (2004).

126. Q. T. Le, P. D. Sutphin, S. Raychaudhuri, S. C. Yu, D. J. Terris, H. S. Lin, B. Lum, H. A. Pinto, A. C. Koong and A. J. Giaccia, Identification of osteopontin as a prognostic plasma marker for head and neck squamous cell carcinomas. Clin. Cancer Res. 9, 59-67 (2003).

127. H. Nishi, K. H. Nishi and A. C. Johnson, Early growth response-1 
gene mediates up-regulation of epidermal growth factor receptor expression during hypoxia. Cancer Res. 62, 827-834 (2002).

128. J. D. Blais, V. Filipenko, M. Bi, H. P. Harding, D. Ron, C. Koumenis, B. G. Wouters and J. C. Bell, Activating transcription factor 4 is translationally regulated by hypoxic stress. Mol. Cell. Biol. 24, 7469-7482 (2004).

129. J. Overgaard, J. G. Eriksen, M. Nordsmark, J. Alsner and M. R. Horsman, Plasma osteopontin, hypoxia, and response to the hypoxia sensitiser nimorazole in radiotherapy of head and neck cancer: results from the DAHANCA 5 randomised double-blind placebo-controlled trial. Lancet Oncol. 6, 757-764 (2005).

130. S. Nuyts, L. Van Mellaert, J. Theys, W. Landuyt, P. Lambin and J. Anne, Clostridium spores for tumor-specific drug delivery. Anticancer Drugs 13, 115-125 (2002).

131. I. Serganova and R. Blasberg, Reporter gene imaging: Potential impact on therapy. Nucl. Med. Biol. 32, 763-780 (2005).

132. G. E. Arteel, R. G. Thurman, J. M. Yates and J. A. Raleigh, Evidence that hypoxia markers detect oxygen gradients in liver: $\mathrm{Pi}$ monidazole and retrograde perfusion of rat liver. Br. J. Cancer $\mathbf{7 2}$, 889-895 (1995).

133. C. J. Koch, S. M. Evans and E. M. Lord, Oxygen dependence of cellular uptake of EF5 [2-(2-nitro-1H-imidazol-1-yl)-N-(2,2,3,3,3pentafluoropropyl)acetamide]: Analysis of drug adducts by fluorescent antibodies vs bound radioactivity. Br. J. Cancer 72, 869-874 (1995).

134. M. W. Gross, U. Karbach, K. Groebe, A. J. Franko and W. Mueller Klieser, Calibration of misonidazole labeling by simultaneous measurement of oxygen tension and labeling density in multicellular spheroids. Int. J. Cancer 61, 567-573 (1995).

135. J. A. Raleigh, G. G. Miller, A. J. Franko, C. J. Koch, A. F. Fuciarelli and D. A. Kelly, Fluorescence immunohistochemical detection of hypoxic cells in spheroids and tumours. Br. J. Cancer 56, 395-400 (1987).

136. J. A. Raleigh, A. J. Franko, E. O. Treiber, J. A. Lunt and P. S. Allen, Covalent binding of a fluorinated 2-nitroimidazole to EMT-6 tumors in Balb/C mice: Detection by F-19 nuclear magnetic resonance at 2.35 T. Int. J. Radiat. Oncol. Biol. Phys. 12, 1243-1245 (1986).

137. J. D. Chapman, A. J. Franko and J. Sharplin, A marker for hypoxic cells in tumours with potential clinical applicability. Br. J. Cancer 43, 546-550 (1981).

138. R. C. Urtasun, J. D. Chapman, J. A. Raleigh, A. J. Franko and C. J. Koch, Binding of ${ }^{3} \mathrm{H}$-misonidazole to solid human tumors as a measure of tumor hypoxia. Int. J. Radiat. Oncol. Biol. Phys. 12, 12631267 (1986).

139. R. C. Urtasun, C. J. Koch, A. J. Franko, J. A. Raleigh and J. D. Chapman, A novel technique for measuring human tissue $p \mathrm{O}_{2}$ at the cellular level. Br. J. Cancer 54, 453-457 (1986).

140. L. M. Cobb, J. Nolan and S. A. Butler, Distribution of pimonidazole and RSU 1069 in tumour and normal tissues. Br. J. Cancer 62, 915-918 (1990).

141. K. M. Laughlin, S. M. Evans, W. T. Jenkins, M. Tracy, C. Y. Chan, E. M. Lord and C. J. Koch, Biodistribution of the nitroimidazole EF5 (2-[2-nitro-1H-imidazol-1-yl]-N-(2,2,3,3,3-pentafluoropropyl) acetamide) in mice bearing subcutaneous EMT6 tumors. J. Pharmacol. Exp. Ther. 277, 1049-1057 (1996).

142. L. Bentzen, S. Keiding, M. R. Horsman, T. Gronroos, S. B. Hansen and J. Overgaard, Assessment of hypoxia in experimental mice tumours by $\left[{ }^{18} \mathrm{~F}\right]$ fluoromisonidazole PET and $p \mathrm{O}_{2}$ electrode measurements. Influence of tumour volume and carbogen breathing. Acta Oncol. 41, 304-312 (2002).

143. C. J. Koch and S. M. Evans, Non-invasive PET and SPECT imaging of tissue hypoxia using isotopically labeled 2-nitroimidazoles. Adv. Exp. Med. Biol. 510, 285-292 (2003).

144. S. M. Evans and C. J. Koch, Prognostic significance of tumor oxygenation in humans. Cancer Lett. 195, 1-16 (2003).

145. R. J. Hodgkiss, G. Jones, A. Long, J. Parrick, K. A. Smith, M. R. Stratford and G. D. Wilson, Flow cytometric evaluation of hypoxic cells in solid experimental tumours using fluorescence immunodetection. Br. J. Cancer 63, 119-125 (1991).
146. D. E. Thrall, M. C. McEntee, J. M. Cline and J. A. Raleigh, ELISA quantification of CCI-103F binding in canine tumors prior to and during irradiation. Int. J. Radiat. Oncol. Biol. Phys. 28, 649-659 (1994).

147. C. Azuma, J. A. Raleigh and D. E. Thrall, Longevity of pimonidazole adducts in spontaneous canine tumors as an estimate of hypoxic cell lifetime. Radiat. Res. 148, 35-42 (1997).

148. R. E. Durand and J. A. Raleigh, Identification of nonproliferating but viable hypoxic tumor cells in vivo. Cancer Res. 58, 3547-3550 (1998).

149. A. S. Kennedy, J. A. Raleigh, G. M. Perez, D. P. Calkins, D. E. Thrall, D. B. Novotny and M. A. Varia, Proliferation and hypoxia in human squamous cell carcinoma of the cervix: First report of combined immunohistochemical assays. Int. J. Radiat. Oncol. Biol. Phys. 37, 897-905 (1997).

150. L. Webster, R. J. Hodgkiss and G. D. Wilson, Simultaneous triple staining for hypoxia, proliferation, and DNA content in murine tumours. Cytometry 21, 344-351 (1995).

151. J. Bussink, J. H. A. M. Kaanders, P. F. J. W. Rijken, J. A. Raleigh and A. J. Van der Kogel, Changes in blood perfusion and hypoxia after irradiation of a human squamous cell carcinoma xenograft tumor line. Radiat. Res. 153, 398-404 (2000).

152. P. F. J. W. Rijken, H. J. J. A. Bernsen, J. P. W. Peters, R. J. Hodgkiss, J. A. Raleigh and A. J. van der Kogel, Spatial relationship between hypoxia and the (perfused) vascular network in a human glioma xenograft: A quantitative multi-parameter analysis. Int. J. Radiat. Oncol. Biol. Phys. 48, 571-582 (2000).

153. A. S. E. Ljungkvist, J. Bussink, P. F. J. W. Rijken, J. A. Raleigh, J. Denekamp and A. J. van der Kogel, Changes in tumor hypoxia measured with a double hypoxic marker technique. Int. J. Radiat. Oncol. Biol. Phys. 48, 1529-1538 (2000).

154. A. S. E. Ljungkvist, J. Bussink, P. F. J. W. Rijken, J. A. Raleigh, J. H. A. M. Kaanders and A. J. van der Kogel, Hypoxic cell turnover in different solid lines. Int. J. Radiat. Oncol. Biol. Phys. 62, $1157-$ 1168 (2005).

155. M. M. Kleiter, D. E. Thrall, D. E. Malarkey, X. Ji, D. Y. Lee, S. C. Chou and J. A. Raleigh, A comparison of oral and intravenous pimonidazole in canine tumors using intravenous CCI-103F as a control hypoxia marker. Int. J. Radiat. Oncol. Biol. Phys. 64, 592-602 (2006).

156. J. S. Rasey, Z. Grunbaum, S. Magee, N. J. Nelson, P. L. Olive, R. E. Durand and K. A. Krohn, Characterization of radiolabeled fluoromisonidazole as a probe for hypoxic cells. Radiat. Res. 111, 292-304 (1987).

157. J. A. Raleigh, A. J. Franko, C. J. Koch and J. L. Born, Binding of misonidazole to hypoxic cells in monolayer and spheroid culture: Evidence that a side-chain label is bound as efficiently as a ring label. Br. J. Cancer 51, 229-235 (1985).

158. A. J. Varghese, Glutathione conjugates of misonidazole. Biochem. Biophys. Res. Commun. 112, 1013-1020 (1983).

159. E. Chacon, C. J. Morrow, A. A. Leon, J. L. Born and B. R. Smith, Regioselective formation of a misonidazole-glutathione conjugate as a function of $\mathrm{pH}$ during chemical reduction. Biochem. Pharmacol. 37, 361-363 (1988).

160. J. A. Raleigh and C. J. Koch, Importance of thiols in the reductive binding of 2-nitroimidazoles to macromolecules. Biochem. Pharmacol. 40, 2457-2464 (1990).

161. S. M. Evans, S. Hahn, D. R. Pook, W. T. Jenkins, A. A. Chalian, P. Zhang, C. Stevens, R. Weber, G. Weinstein and C. J. Koch, Detection of hypoxia in human squamous cell carcinoma by EF5 binding. Cancer Res. 60, 2018-2024 (2000).

162. M. A. Varia, D. P. Calkins Adams, L. H. Rinker, A. S. Kennedy, D. B. Novotny, W. C. Fowler, Jr. and J. A. Raleigh, Pimonidazole: A novel hypoxia marker for complementary study of tumor hypoxia and cell proliferation in cervical carcinoma. Gynecol. Oncol. 71, 270-277 (1998)

163. K. Lehtio, O. Eskola, T. Viljanen, V. Oikonen, T. Gronroos, L. Sillanmaki, R. Grenman and H. Minn, Imaging perfusion and hypoxia 
with PET to predict radiotherapy response in head-and-neck cancer. Int. J. Radiat. Oncol. Biol. Phys. 59, 971-982 (2004).

164. D. Sorger, M. Patt, P. Kumar, L. I. Wiebe, H. Barthel, A. Seese, C. Dannenberg, A. Tannapfel, R. Kluge and O. Sabri, $\left[{ }^{18} \mathrm{~F}\right]$ Fluoroazo mycinarabinofuranoside $\left({ }^{18} \mathrm{FAZA}\right)$ and $\left[{ }^{18} \mathrm{~F}\right]$ fluoromisonidazole ( $\left.{ }^{18} \mathrm{FMISO}\right)$ : A comparative study of their selective uptake in hypoxic cells and PET imaging in experimental rat tumors. Nucl. Med. Biol. 30, 317-326 (2003).

165. T. Gronroos, L. Bentzen, P. Marjamaki, R. Murata, M. R. Horsman, S. Keiding, O. Eskola, M. Haaparanta, H. Minn and O. Solin, Comparison of the biodistribution of two hypoxia markers $\left[{ }^{18} \mathrm{~F}\right]$ FETNIM and $\left[{ }^{18} \mathrm{~F}\right] \mathrm{FMISO}$ in an experimental mammary carcinoma. Eur. $J$. Nucl. Med. Mol. Imaging 31, 513-520 (2004).

166. S. M. Eschmann, F. Paulsen, M. Reimold, H. Dittmann, S. Welz, G. Reischl, H. J. Machulla and R. Bares, Prognostic impact of hypoxia imaging with ${ }^{18} \mathrm{~F}-$ misonidazole PET in non-small cell lung cancer and head and neck cancer before radiotherapy. J. Nucl. Med. 46, 253-260 (2005).

167. R. J. Hicks, D. Rischin, R. Fisher, D. Binns, A. M. Scott and L. J. Peters, Utility of FMISO PET in advanced head and neck cancer treated with chemoradiation incorporating a hypoxia-targeting chemotherapy agent. Eur. J. Nucl. Med. Mol. Imaging 32, 1384-1391 (2005).

168. B. J. Krause, R. Beck, M. Souvatzoglou and M. Piert, PET and PET/CT studies of tumor tissue oxygenation. Q. J. Nucl. Med. Mol. Imaging 50, 28-43 (2006).

169. W. J. Koh, K. S. Bergman, J. S. Rasey, L. M. Peterson, M. L. Evans, M. M. Graham, J. R. Grierson, K. L. Lindsley, T. K. Lewellen and K. A. Krohn, Evaluation of oxygenation status during fractionated radiotherapy in human nonsmall cell lung cancers using [F-18]fluoromisonidazole positron emission tomography. Int. J. Radiat. Oncol. Biol. Phys. 33, 391-398 (1995).

170. J. S. Rasey, W. J. Koh, M. L. Evans, L. M. Peterson, T. K. Lewellen, M. M. Graham and K. A. Krohn, Quantifying regional hypoxia in human tumors with positron emission tomography of $\left[{ }^{18} \mathrm{~F}\right]$ fluoromisonidazole: A pretherapy study of 37 patients. Int. J. Radiat. Oncol. Biol. Phys. 36, 417-428 (1996).

171. R. J. Hodgkiss, Use of 2-nitroimidazoles as bioreductive markers for tumour hypoxia. Anticancer Drug Des. 13, 687-702 (1998).

172. R. J. Hodgkiss, M. R. Stratford, M. F. Dennis and S. A. Hill, Pharmacokinetics and binding of the bioreductive probe for hypoxia, NITP: Effect of route of administration. Br. J. Cancer 72, 1462 1468 (1995).

173. E. M. Lord, L. Harwell and C. J. Koch, Detection of hypoxic cells by monoclonal antibody recognizing 2-nitroimidazole adducts. Cancer Res. 53, 5721-5726 (1993).

174. J. A. Raleigh, E. M. Zeman, M. Rathman, J. K. LaDine, J. M. Cline and D. E. Thrall, Development of an ELISA for the detection of 2nitroimidazole hypoxia markers bound to tumor tissue. Int. J. Radiat. Oncol. Biol. Phys. 22, 403-405 (1992).

175. P. L. Olive, D. J. Chaplin and R. E. Durand, Pharmacokinetics, binding and distribution of Hoechst 33342 in spheroids and murine tumours. Br. J. Cancer 52, 739-746 (1985).

176. J. A. Raleigh, S. C. Chou, D. P. Calkins Adams, C. A. Ballenger, D. B. Novotny and M. A. Varia, A clinical study of hypoxia and metallothionein protein expression in squamous cell carcinomas. Clin. Cancer Res. 6, 855-862 (2000).

177. K. I. E. M. Wijffels, J. H. A. M. Kaanders, H. A. M. Marres, J. Bussink, H. P. W. Peters, P. F. J. W. Rijken, P. C. M. de Wilde and A. J. van der Kogel, Patterns of proliferation related to vasculature in human head-and-neck carcinomas before and after transplanatation in nude mice. Int. J. Radiat. Oncol. Biol. Phys. 51, 1346-1353 (2001).

178. J. A. Raleigh, S. C. Chou, E. L. Bono, D. E. Thrall and M. A. Varia, Semiquantitative immunohistochemical analysis for hypoxia in human tumors. Int. J. Radiat. Oncol. Biol. Phys. 49, 569-574 (2001).

179. I. J. Hoogsteen, L. A. M. Pop, H. A. M. Marres, M. A. W. Merkx, F. J. A. van den Hoogen, A. J. van der Kogel and J. H. A. M. Kaanders, Oxygen-modifying treatment with ARCON reduces the prognostic significance of hemoglobin in squamous cell carcinoma of the head and neck. Int. J. Radiat. Oncol. Biol. Phys. 64, 83-89 (2005).

180. J. A. Raleigh, S. C. Chou, G. E. Arteel and M. R. Horsman, Comparisons among pimonidazole binding, oxygen electrode measurements, and radiation response in $\mathrm{C} 3 \mathrm{H}$ mouse tumors. Radiat. Res. 151, 580-589 (1999).

181. M. Nordsmark, J. Loncaster, C. Aquino-Parsons, S. C. Chou, M. Ladekarl, H. Havsteen, J. C. Lindegaard, S. E. Davidson, M. Varia and J. A. Raleigh, Measurements of hypoxia using pimonidazole and polarographic oxygen-sensitive electrodes in human cervix carcinomas. Radiother. Oncol. 67, 35-44 (2003).

182. M. Nordsmark, J. Loncaster, S. C. Chou, H. Havsteen, J. C. Lindegaard, S. E. Davidson, M. Varia, C. West, R. Hunter and J. A. Raleigh, Invasive oxygen measurements and pimonidazole labeling in human cervix carcinoma. Int. J. Radiat. Oncol. Biol. Phys. 49, 581-586 (2001).

183. W. T. Jenkins, S. M. Evans and C. J. Koch, Hypoxia and necrosis in rat 9L glioma and Morris 7777 hepatoma tumors: Comparative measurements using EF5 binding and the Eppendorf needle electrode. Int. J. Radiat. Oncol. Biol. Phys. 46, 1005-1017 (2000).

184. J. Bussink, J. H. A. M. Kaanders, P. F. J. W. Rijken, J. P. W. Peters, R. J. Hodgkiss, H. A. Marres and A. J. van der Kogel, Vascular architecture and microenvironmental parameters in human squamous cell carcinoma xenografts: Effects of carbogen and nicotinamide. Radiother. Oncol. 50, 173-184 (1999).

185. J. Schuuring, J. Bussink, H. J. Bernsen, W. Peeters and A. J. van der Kogel, Irradiation combined with SU5416: Microvascular changes and growth delay in a human xenograft glioblastoma tumor line. Int. J. Radiat. Oncol. Biol. Phys. 61, 529-534 (2005).

186. K. A. Smith, S. A. Hill, A. C. Begg and J. Denekamp, Validation of the fluorescent dye Hoechst 33342 as a vascular space marker in tumours. Br. J. Cancer 57, 247-253 (1988).

187. P. L. Olive and R. E. Durand, Characterization of a carbocyanine derivative as a fluorescent penetration probe. Cytometry 8, 571-575 (1987).

188. M. J. Trotter, D. J. Chaplin and P. L. Olive, Use of a carbocyanine dye as a marker of functional vasculature in murine tumours. $B r$. $J$. Cancer 59, 706-709 (1989).

189. K. L. Bennewith and R. E. Durand, Quantifying transient hypoxia in human tumor xenografts by flow cytometry. Cancer Res. 64, 6183-6189 (2004).

190. R. V. Iyer, E. Kim, R. F. Schneider and J. D. Chapman, A dual hypoxic marker technique for measuring oxygenation change within individual tumors. Br. J. Cancer 78, 163-169 (1998).

191. H. W. M. van Laarhoven, J. Bussink, J. Lok, C. J. A. Punt, A. Heerschap and A. J. van der Kogel, Effects of nicotinamide and carbogen in different murine colon carcinomas: immunohistochemical analysis of vascular architecture and microenvironmental parameters. Int. J. Radiat. Oncol. Biol. Phys. 60, 310-321 (2004).

192. A. S. E. Ljungkvist, J. Bussink, J. H. A. M. Kaanders, N. E. Wiedenmann, R. Vlasman and A. J. van der Kogel, Dynamics of hypoxia, proliferation and apoptosis in a murine tumor model after irradiation. Radiat. Res. 165, 326-336 (2006).

193. D. G. Hirst, J. Denekamp and B. Hobson, Proliferation kinetics of endothelial and tumour cells in three mouse mammary carcinomas. Cell. Tissue. Kinet. 15, 251-261 (1982).

194. R. E. Durand and E. Sham, The lifetime of hypoxic human tumor cells. Int. J. Radiat. Oncol. Biol. Phys. 42, $711-715$ (1998).

195. G. E. Gifford, Some effects of anaerobiosis on the growth and metabolism of HeLa cells. Exp. Cell Res. 31, 113-118 (1962).

196. B. Littbrand and L. Revesz, Survival of cells in anoxia. Br. J. Radiol. 41, 479-480 (1968).

197. C. J. Koch, J. Kruuv and H. E. Frey, The effect of hypoxia on the generation time of mammalian cells. Radiat. Res. 53, 43-48 (1973).

198. C. J. Koch, J. Kruuv, H. E. Frey and R. A. Snyder, Plateau phase in growth induced by hypoxia. Int. J. Radiat. Biol. Relat. Stud. Phys. Chem. Med. 23, 67-74 (1973). 
199. R. F. Kallman, The phenomenon of reoxygenation and its implications for fractionated radiotherapy. Radiology 105, 135-142 (1972).

200. P. L. Olive, Radiation-induced reoxygenation in the SCCVII murine tumour: Evidence for a decrease in oxygen consumption and an increase in tumour perfusion. Radiother. Oncol. 32, 37-46 (1994).

201. R. Murata, Y. Shibamoto, K. Sasai, N. Oya, T. Shibata, T. Takagi and $\mathrm{M}$. Abe, Reoxygenation after single irradiation in rodent tumors of different types and sizes. Int. J. Radiat. Oncol. Biol. Phys. 34, 859-865 (1996).

202. I. H. Kim and J. M. Brown, Reoxygenation and rehypoxiation in the SCCVII mouse tumor. Int. J. Radiat. Oncol. Biol. Phys. 29, 493497 (1994).

203. N. Crokart, B. F. Jordan, C. Baudelet, R. Ansiaux, O. Sonveuax, V. Gregoire, N. Begheon, J. d. Wever, C. Bouzin and B. Gallez, Early reoxygenation in tumors after irradiation: Determining factors and consequences for radiotherapy regimens using daily multiple fractions. Int. J. Radiat. Oncol. Biol. Phys. 63, 901-910 (2005).

204. J. D. Chapman, E. L. Engelhardt, C. C. Stobbe, R. F. Schneider and G. E. Hanks, Measuring hypoxia and predicting tumor radioresistance with nuclear medicine assays. Radiother. Oncol. 46, 229-237 (1998).

205. A. J. Franko, C. J. Koch, B. M. Garrecht, J. Sharplin and D. Hughes, Oxygen dependence of binding of misonidazole to rodent and human tumors in vitro. Cancer Res. 47, 5367-5376 (1987).

206. A. I. Minchinton and M. R. Stratford, A comparison of tumor and normal tissue levels of acidic, basic and neutral 2-nitroimidazole radiosensitizers in mice. Int. J. Radiat. Oncol. Biol. Phys. 12, 1117 1120 (1986).

207. C. J. Koch, S. M. Hahn, K. Rockwell, Jr., J. M. Covey, W. G. McKenna and S. M. Evans, Pharmacokinetics of EF5 [2-(2-nitro-1-
H-imidazol-1-yl)-N-(2,2,3,3,3-pentafluoropropyl) acetamide] in human patients: implications for hypoxia measurements in vivo by 2 nitroimidazoles. Cancer Chemother. Pharmacol. 48, 177-187 (2001).

208. J. D. Chapman, K. Baer and J. Lee, Characteristics of the metabolism-induced binding of misonidazole to hypoxic mammalian cells. Cancer Res. 43, 1523-1528 (1983).

209. L. Webster, R. J. Hodgkiss and G. D. Wilson, Cell cycle distribution of hypoxia and progression of hypoxic tumour cells in vivo. Br. J. Cancer 77, 227-234 (1998).

210. R. J. Hodgkiss, L. Webster and G. D. Wilson, Measurement of hypoxia in vivo using a 2-nitroimidazole (NITP). Adv. Exp. Med. Biol. 428, 61-67 (1997).

211. J. M. Cline, D. E. Thrall, R. L. Page, A. J. Franko and J. A. Raleigh, Immunohistochemical detection of a hypoxia marker in spontaneous canine tumours. Br. J. Cancer 62, 925-931 (1990).

212. M. I. Saunders, P. J. Anderson, M. H. Bennett, S. Dische, A. Minchinton, M. R. Stratford and M. Tothill, The clinical testing of Ro 03-8799-pharmacokinetics, toxicology, tissue and tumor concentrations. Int. J. Radiat. Oncol. Biol. Phys. 10, 1759-1763 (1984).

213. M. I. Walton, N. M. Bleehen and P. Workman, The reversible Noxidation of the nitroimidazole radiosensitizer Ro 03-8799. Biochem. Pharmacol. 34, 3939-3940 (1985).

214. S. M. Evans, W. T. Jenkins, B. Joiner, E. M. Lord and C. J. Koch, 2-Nitroimidazole (EF5) binding predicts radiation resistance in individual 9L s.c. tumors. Cancer Res. 56, 405-411 (1996).

215. S. M. Evans, B. Joiner, W. T. Jenkins, K. M. Laughlin, E. M. Lord and C. J. Koch, Identification of hypoxia in cells and tissues of epigastric 9L rat glioma using EF5 [2-(2-nitro-1H-imidazol-1-yl)$\mathrm{N}$-(2,2,3,3,3-pentafluoropropyl) acetamide]. Br. J. Cancer 72, 875882 (1995). 